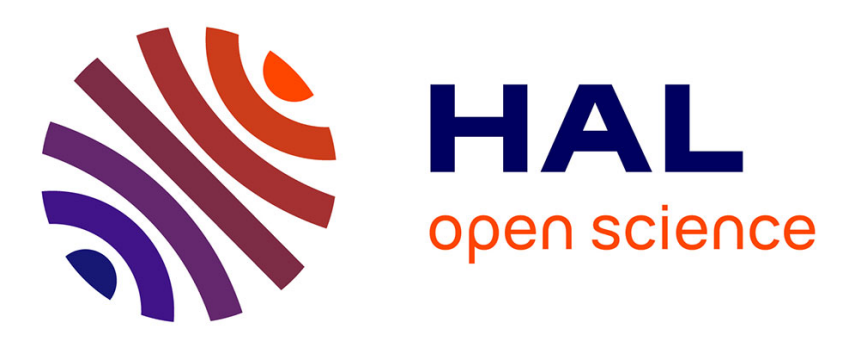

\title{
Distribution of AC Electric Field-Induced Transmembrane Voltage in Escherichia coli Cell Wall Layers
}

Dominique Rauly, Médéric Vindret, Eric Chamberod, Jean Martins, Pascal Xavier

\section{To cite this version:}

Dominique Rauly, Médéric Vindret, Eric Chamberod, Jean Martins, Pascal Xavier. Distribution of AC Electric Field-Induced Transmembrane Voltage in Escherichia coli Cell Wall Layers. Bioelectromagnetics, 2020, 41 (4), pp.279-288. 10.1002/bem.22261 . hal-03086538

\section{HAL Id: hal-03086538 \\ https://hal.science/hal-03086538}

Submitted on 12 Feb 2021

HAL is a multi-disciplinary open access archive for the deposit and dissemination of scientific research documents, whether they are published or not. The documents may come from teaching and research institutions in France or abroad, or from public or private research centers.
L'archive ouverte pluridisciplinaire HAL, est destinée au dépôt et à la diffusion de documents scientifiques de niveau recherche, publiés ou non, émanant des établissements d'enseignement et de recherche français ou étrangers, des laboratoires publics ou privés.

\section{(c) (1) $\$$}

Distributed under a Creative Commons Attribution - NonCommercial| 4.0 International 


\title{
Distribution of AC-electric-field-induced transmembrane voltage in Escherichia coli cell wall layers
}

\author{
D. Rauly',2, M. Vindret ${ }^{1}$, E. Chamberod ${ }^{2}$, J.M.F. Martins ${ }^{2,3}$ and P. Xavier ${ }^{1,2}$ \\ 1. IMEP-LAHC, UMR 5130 CNRS/G-INP/UGA; 2. University Grenoble-Alpes (UGA); 3. IGE, UMR 5564, \\ CNRS/G-INP/UGA/IRD; email: mederic.vindret@grenoble-inp.fr
}

\begin{abstract}
Based on gram-negative bacterium $E$. coli models previously published in the literature, the transmembrane voltage induced by the application of an $\mathrm{AC}$ electric field on a bacterial suspension is calculated using COMSOL $^{\mathrm{TM}}$ Multiphysics software, in the range $1 \mathrm{MHz}-20 \mathrm{MHz}$, for longitudinal and transversal field orientations. The voltages developed on each of the three layers of the cell wall are then calculated using an electrical equivalent circuit. This study shows that the overall voltage on the cell wall, whose order of magnitude is a few tens of $\mu \mathrm{V}$, is mainly distributed on inner and outer layers, while a near-zero voltage is found on the periplasm, due to its much higher electrical conductivity compared to the other layers. Although the outer membrane electrical conductivity taken in the model is a thousand times higher than that of the inner membrane, the voltage there is about half of that on the inner membrane, due to capacitive effects. It follows that the expression of protein complexes anchored in the inner membrane could potentially be disrupted, inducing in particular a possible perturbation of biological processes related to cellular respiration and protons cycle, and leading to growth inhibition as a consequence. Protein complexes anchored in the outer membrane, or constituting a bridge between the three layers of the cell wall, such as some porins, may also undergo the same action, which would add another growth inhibition factor, as a result of deficiency in porin filtration function when the external environment contains biocides.
\end{abstract}

\section{Introduction}

In recent years, research to counteract microbial proliferation in aqueous media has shifted to non-lethal solutions [Giladi et al, 2008], [Giladi et al, 2010], [Zituni et al., 2014], [Jain et al., 2015], [Abo-Neima et al., 2016]. Less penalizing, in terms of energy consumption and pollution, than traditional lethal methods, these new approaches aim to limit or even stop microbial growth by influencing the metabolism of microorganisms.

Thus, instead of acting on the energetic level by destroying bacteria, it is preferred conceptually to operate on the functional level, by disrupting essential functions such as cellular respiration, ion exchange or processes involved in mitosis.

It has been demonstrated that these effects can be achieved in particular by the application of an external variable weak electric field with a frequency ranging between a few $100 \mathrm{kHz}$ and several $10 \mathrm{MHz}$ [Giladi et al, 2008]. This is referred to the electricidal effect [Del Pozo et al., 2009]. However, the details of the growth inhibition mechanism are not yet clearly explained. We know little about how to precisely identify the functions affected, or 
how to state which protein complexes are destabilized by the treatment, in case of weak external electric field application.

Nevertheless, knowing that some protein complexes of the cell wall are electrically sensitive (Tsong 1990), it may be assumed that some categories of these protein complexes are potentially disrupted during the application of an external AC electrical field. Indeed, when such a treatment is applied to a bacterial suspension in a nutrient medium, the cell wall is the site of a much larger variable field than the cytoplasm, due to its very low electrical conductivity. Therefore, it could be interesting to focus our investigations on membrane proteins and identify those that are subjected to the highest induced AC voltage.

This theoretical paper, using COMSOL ${ }^{\mathrm{TM}}$ Multiphysics modeling, and equivalent electrical circuits, is intended to provide potentially explanatory elements for the process of inhibiting bacterial growth by applying an $\mathrm{AC}$ electric field. Focused on the gram-negative bacteria $E$. coli, we use a conceptual model developed previously [Xavier et al, 2017], in order to control boundary conditions close to the bacteria for the simulation.

Based on a published model [Bai et al, 2006], a theoretical transfer function is established, allowing the $\mathrm{AC}$ voltage on each of the three layers of the cell wall to be deduced from the results of the COMSOL ${ }^{\mathrm{TM}}$ numerical simulation. This is performed for two orientations of the applied electric field (longitudinal and transversal). A discussion is finally initiated, taking as examples, in a non-exhaustive way, some protein complexes and some associated biological functions.

\section{Modeling}

The problem refers to bacteria (Escherichia coli DH5 $\alpha$ ) in suspension in a physiological medium serum (electrical conductivity $\sigma_{\mathrm{e}}=1.3 \mathrm{~S} / \mathrm{m}$; relative permittivity $\varepsilon_{\mathrm{re}}=80$ ), submitted to an $\mathrm{AC}$ voltage. It is aimed to perform numerical simulations of the electrical quantities induced in a single bacterial cell, using the Finite-Element software COMSOL.

As explained in [Xavier et al, 2017] relevant simulations, corresponding to this problem, are achieved when boundary conditions in the form of imposed potentials are applied on opposite surfaces of a cubic volume surrounding the bacterium (Figure 1). This configuration leads to the possibility of cascading the elementary boxes, in order to obtain a macroscopic model of the entire bacterial suspension. Each of these elementary cubic boxes must have a minimum side, depending on the size of the bacterium and its orientation relative to the direction of the applied external electric field. It was determined that $\mathrm{a}=4.6 \mu \mathrm{m}$ is suitable for the standard dimensions given in Figure 2 and for all orientations.

The present paper deals with the study of longitudinal and transversal orientations, as detailed on figure 1. 
1

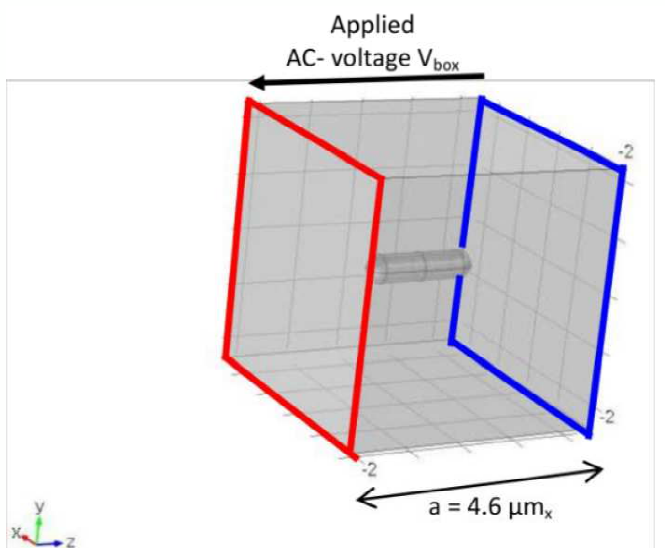

Figure 1-a

Elementary box with a single longitudinally excited cell, numerically studied using $\mathrm{COMSOL}^{\mathrm{TM}}$ multiphysics

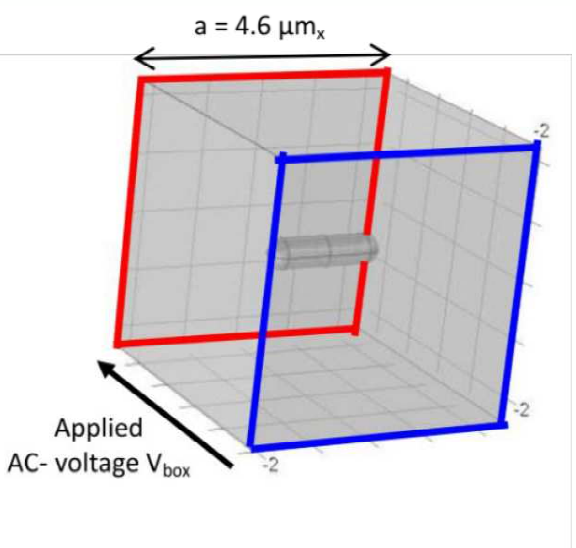

Figure 1-b

Elementary box with a single transversally excited cell, numerically studied using COMSOL ${ }^{\mathrm{TM}}$ multiphysics

In addition, a single bacterial cell model was established in [Xavier et al, 2017] (Figure 2). The cytoplasm (electrical conductivity $\sigma_{\mathrm{c}}=0.22 \mathrm{~S} / \mathrm{m}$; relative permittivity $\varepsilon_{\mathrm{rc}}=40$ ) is surrounded by a cell wall (thickness $d=24 \mathrm{~nm}$ ), modeled as a monolayer equivalent to the three characteristics layers of Gram-negative bacteria.

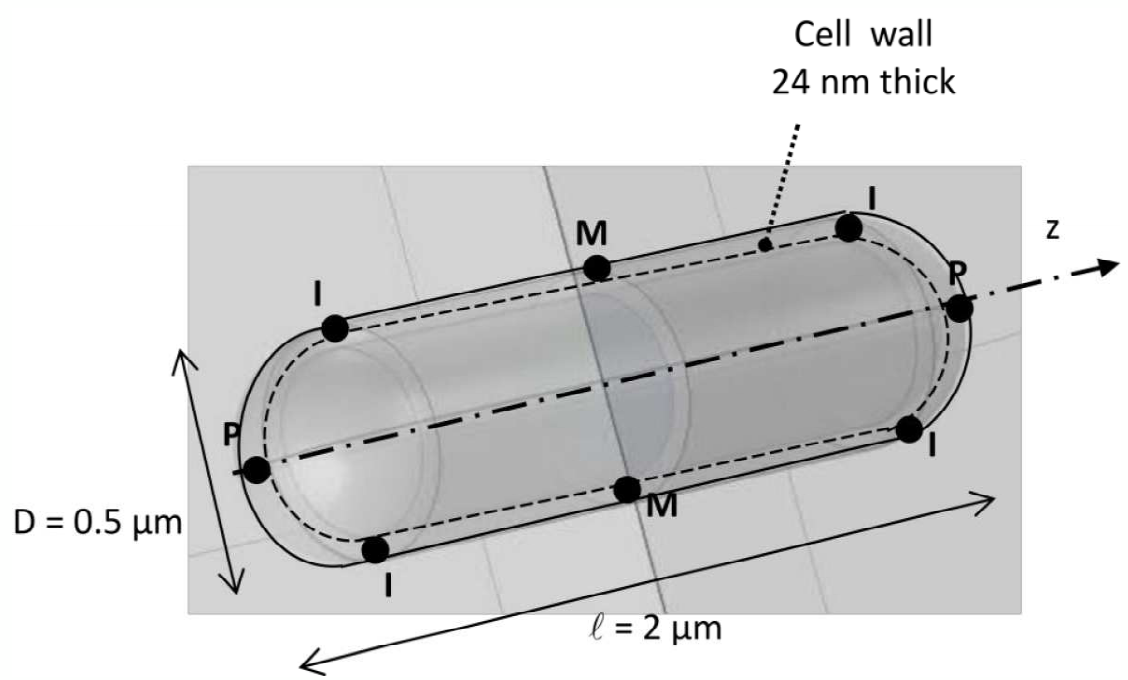

Figure 2 - COMSOL model of Escherichia coli with equivalent monolayer cell wall. The induced transmembrane AC voltage is calculated at the points marked respectively $\mathbf{P}$ (pole), $\mathbf{M}$ (middle) and $\mathbf{I}$ (intermediate).

The electrical properties of this equivalent cell wall, valid in the 1-20 MHz frequency band, were determined on the basis of previous work in the literature [Bai et al, 2006]. They are detailed in Table 1. 


\begin{tabular}{|c|c|c|c|c}
\hline & Inner membrane & Periplasm & Outer membrane & Equivalent cell \\
\hline Thickness (nm) & 7 & 10 & 7 & 24 \\
\hline $\begin{array}{c}\text { Relative dielectric } \\
\text { permittivity }\end{array}$ & 5.5 & 60 & 12.1 & 13.6 \\
\hline $\begin{array}{c}\text { Electrical } \\
\text { conductivity (S/m) }\end{array}$ & $10^{-7}$ & 3.2 & $10^{-4}$ & $3.7 \times 10^{-5}$ \\
\hline
\end{tabular}

Table 1 - Characteristics of the layers constituting the cell wall used for modeling purposes.

Numerical values mentioned in Table 1 should be considered with some care regarding the underlying work hypotheses, i.e.:

- The authors in the paper [Bai et al., 2006] provide a range of possible values, taking into account the extraction method corresponding to the 3-shell model. In this article we selected realistic values, more or less in the center of the proposed ranges.

- The validity of the frequency band is limited, typically from $1 \mathrm{MHz}$ to $20 \mathrm{MHz}$. This range is also the one used when simplifying the model in the paper, where a monolayer equivalent to the three layers of the cell wall was determined.

- The values in Table 1 are elaborated on the assumption that each of the three layers of the 3 -shell model has uniform characteristics. They therefore correspond to averaging, knowing that the real cell wall exhibits disparities, particularly linked to the presence of anchored proteins.

- The data were extracted from specific experimental conditions. The bacteria were resuspended in a non-nutritive medium, resulting in a particular conformation of the ion channels, which modifies the equivalent surface impedance of the cell wall compared to a situation where the bacteria live in a normally nutritious medium, such as LB medium.

\section{Numerical Results: induced transmembrane AC voltage}

Figures 3 and 4 show the induced transmembrane AC voltage amplitudes, calculated numerically with $\mathrm{COMSOL}^{\mathrm{TM}}$ Multiphysics software, when an electric field of amplitude $1 \mathrm{~V} / \mathrm{cm}$ is applied, in longitudinal and transversal directions respectively. As detailed in Figure 2 , the calculation points are located at the pole (P), in the middle (M) and at an intermediate point (I) of the bacterial cell, the latter being at the beginning of the hemispheric part.

As a result of the existing symmetry with respect to both the transversal (xoy fig. 1) and longitudinal (yoz fig. 1) cross-sectional planes, whatever the direction of the field applied, all points $\mathrm{P}$ (see Figure 2) are subject to the same voltage,. The same applies to points $\mathrm{M}$ and I.

When the field is applied longitudinally, the transmembrane voltage induced at the $\mathrm{M}$ points (not shown here) is zero, because the equatorial plane to the bacterium is equipotential. This observation may be important, as the transversal plane is the site of key proteins during the mitosis process. This is particularly the case for the Fts Z ring.

Conversely, the $\mathrm{P}$ poles are the seats of the highest induced voltage. The latter is maximum at the lowest frequencies, because the cell wall presents itself as an almost pure capacity due to 
its low electrical conductivity. The same frequency behavior is found for the intermediate points I.

With an external electric field amplitude of $1 \mathrm{~V} / \mathrm{cm}$, the maximum induced AC voltage at the poles $(95 \mu \mathrm{V}$ at $1 \mathrm{MHz})$ is much lower than the order of magnitude of the DC transmembrane resting potential, the latter being around a few $100 \mathrm{mV}$ depending on the conditions (external $\mathrm{pH}$, growth phase, etc.) [Zilberstein et al., 1984] [Bot et al., 2010]. The transmembrane potential is therefore very weakly modulated by the AC component, which could lead to predictions of negligible consequences on the metabolism of the microorganism. Nevertheless, growth inhibition effects were observed with fields of the same order of magnitude as the one used in the simulation [Giladi et al., 2008].

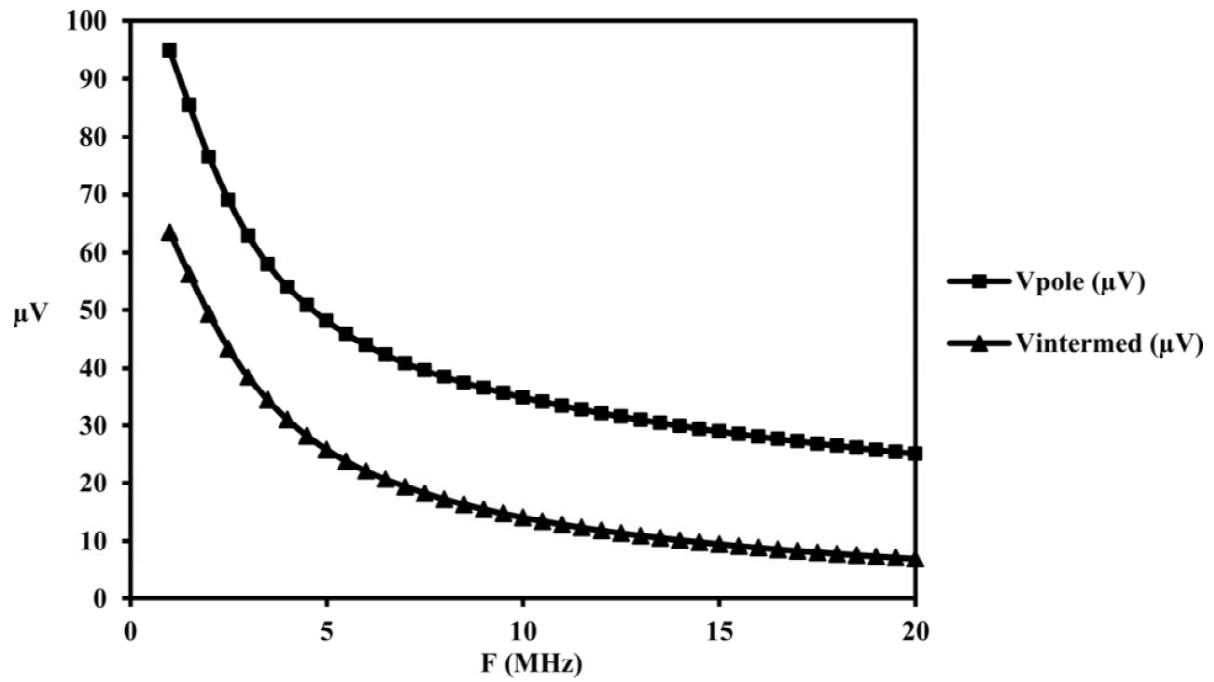

Figure 3 - Computed transmembrane AC voltage with a longitudinally applied electric field of amplitude $1 \mathrm{~V} / \mathrm{cm}$, at points $\mathrm{P}$ (poles) $(\boldsymbol{-})$ and I (intermediate) $(\boldsymbol{\Delta})$ visibles on figure 2. Voltage at middle points $\mathrm{M}$ is zero.

When the electric field is applied transversely, the induced voltage is now zero at poles $\mathrm{P}$ and maximum at mid-points $\mathrm{M}$. The frequency behaviour is similar to that obtained with longitudinal excitation, except that the decrease, the voltage values and the variation between the points are smaller. This result confirms the interest of combining the two orientations during electricidal treatment, as done in the reference [Giladi et al., 2008].

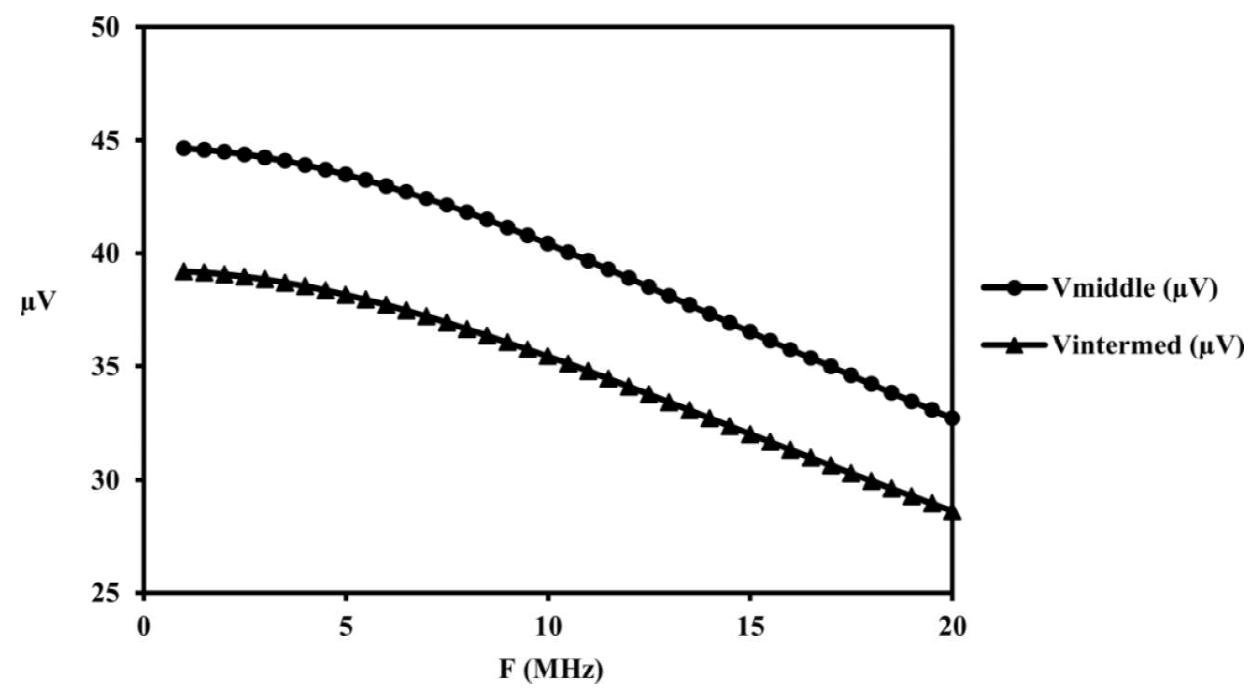


Figure 4 - Computed transmembrane AC voltage with a transversally applied electric field of

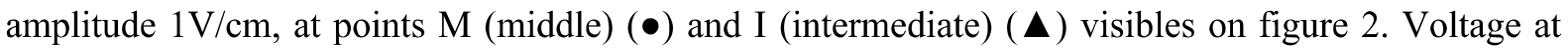
poles $\mathrm{P}$ is zero.

\section{Voltage Membrane Transfer Functions}

This chapter aims to detail how the voltages previously calculated are distributed in each of the three sub-layers constituting the cell wall of the gram-negative bacteria, namely the phospholipidic inner membrane, the periplasm and the lipopolysaccharide (LPS) outer membrane.

To achieve this, it is required to determine the transfer functions of the type:

$$
\mathrm{T}_{\mathrm{idB}}=20 \log _{10}\left(\frac{\mathrm{V}_{\mathrm{i}}}{\mathrm{V}_{\text {tot-wall }}}\right)
$$

where $\mathrm{V}_{\mathrm{i}}$ and $\mathrm{V}_{\text {tot-wall }}$ are the amplitude of the $\mathrm{AC}$ voltage on layer $\mathrm{i}$ and whole cell wall respectively.

The equivalent electrical circuit of a unit area of the Gram-negative cell wall can be established, as shown on Figure 5.

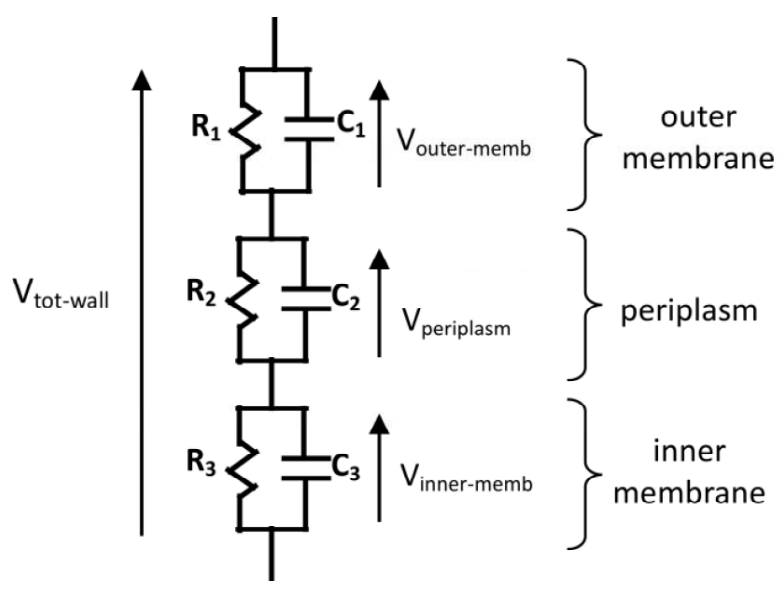

Figure 5 - Equivalent electrical circuit of a unit area of the Gram-negative cell wall, detailing each sublayer.

The specific resistances and capacitances values of this equivalent circuit are calculated from data of Table 1 and given on Table 2, where :

$$
\begin{aligned}
& \mathrm{R}_{\mathrm{i}}=\frac{1}{\sigma_{\mathrm{i}}} \cdot \frac{\mathrm{d}_{\mathrm{i}}}{\mathrm{S}} \\
& \mathrm{C}_{\mathrm{i}}=\varepsilon_{\mathrm{o}} \varepsilon_{\mathrm{i}} \frac{\mathrm{S}}{\mathrm{d}_{\mathrm{i}}}
\end{aligned}
$$


$\mathrm{d}_{\mathrm{i}}, \sigma_{\mathrm{i}}$ and $\varepsilon_{\mathrm{i}}$ are respectively the thickness, electrical conductivity and relative dielectric permittivity of layer $i$. $S$ is the specific surface area chosen for the calculation, here $S=10^{-8} \mathrm{~m}^{2}$, reminding that this choice does not affect the final expression of the transfer function.

\begin{tabular}{|c|c|c|}
\hline & $\mathrm{R}_{\mathrm{i}}$ & $\mathrm{C}_{\mathrm{i}}$ \\
\hline Outer membrane & $7 \mathrm{k} \Omega$ & $153 \mathrm{pF}$ \\
\hline Periplasm & $0,312 \Omega$ & $531 \mathrm{pF}$ \\
\hline Inner membrane & $7 \times 10^{6} \Omega$ & $69,5 \mathrm{pF}$ \\
\hline
\end{tabular}

Table 2 - Specific resistances and capacitances calculated for the three sublayers of $E$. coli cell wall, with $S=10^{-8} \mathrm{~m}^{2}$

The transfer function express, at pulsation $\omega$, the ratio of the voltage on layer $i$ to the total cell wall voltage and is written :

$$
\mathrm{T}_{\mathrm{i}}=\frac{\mathrm{V}_{\mathrm{i}}}{\mathrm{V}_{\text {tot-wall }}}=\frac{\frac{\mathrm{R}_{\mathrm{i}}}{1+\mathrm{j} \omega \tau_{\mathrm{i}}}}{\frac{\mathrm{R}_{\mathrm{i}}}{1+\mathrm{j} \omega \tau_{\mathrm{i}}}+\frac{\mathrm{R}_{\mathrm{j}}}{1+\mathrm{j} \omega \tau_{\mathrm{j}}}+\frac{\mathrm{R}_{\mathrm{k}}}{1+\mathrm{j} \omega \tau_{\mathrm{k}}}}
$$

where subscripts $\mathrm{j}$ and $\mathrm{k}$ refer to the other layers $(\mathrm{j} \neq \mathrm{i}$ and $\mathrm{k} \neq \mathrm{i}$ ), and $\tau_{\mathrm{i}}=\mathrm{R}_{\mathrm{i}} \cdot \mathrm{C}_{\mathrm{i}} ; \tau_{\mathrm{j}}=\mathrm{R}_{\mathrm{j}} \cdot \mathrm{C}_{\mathrm{j}} ; \tau_{\mathrm{k}}=\mathrm{R}_{\mathrm{k}} \cdot \mathrm{C}_{\mathrm{k}}$.

After some developments, it comes from equation (4):

$$
T_{i}=K_{i} \cdot \frac{\left(1+j \omega \tau_{j}\right) \cdot\left(1+j \omega \tau_{k}\right)}{1+2 z \frac{j \omega}{\omega_{n}}+\left(\frac{j \omega}{\omega_{n}}\right)^{2}}
$$

where :

$$
\begin{array}{cc}
\mathrm{K}_{\mathrm{i}}=\frac{\mathrm{R}_{\mathrm{i}}}{\mathrm{R}_{\mathrm{i}}+\mathrm{R}_{\mathrm{j}}+\mathrm{R}_{\mathrm{k}}} & \text { (6) : } \mathrm{T}_{\mathrm{i}} \text { low frequency limit } \\
\omega_{\mathrm{n}}=\sqrt{\frac{\mathrm{R}_{\mathrm{i}}+\mathrm{R}_{\mathrm{j}}+\mathrm{R}_{\mathrm{k}}}{\mathrm{R}_{\mathrm{i}} \tau_{\mathrm{j}} \tau_{\mathrm{k}}+\mathrm{R}_{\mathrm{j}} \tau_{\mathrm{i}} \tau_{\mathrm{k}}+\mathrm{R}_{\mathrm{k}} \tau_{\mathrm{i}} \tau_{\mathrm{j}}}} & \text { (7) : natural pulsation } \\
\mathrm{z}=\frac{1}{2 \sqrt{\mathrm{R}_{\mathrm{i}}+\mathrm{R}_{\mathrm{j}}+\mathrm{R}_{\mathrm{k}}}} \cdot\left(\frac{\mathrm{R}_{\mathrm{i}}\left(\tau_{\mathrm{j}}+\tau_{\mathrm{k}}\right)+\mathrm{R}_{\mathrm{j}}\left(\tau_{\mathrm{i}}+\tau_{\mathrm{k}}\right)+\mathrm{R}_{\mathrm{k}}\left(\tau_{\mathrm{i}}+\tau_{\mathrm{j}}\right)}{\sqrt{\mathrm{R}_{\mathrm{i}} \tau_{\mathrm{j}} \tau_{\mathrm{k}}+\mathrm{R}_{\mathrm{j}} \tau_{\mathrm{i}} \tau_{\mathrm{k}}+\mathrm{R}_{\mathrm{k}} \tau_{\mathrm{i}} \tau_{\mathrm{j}}}}\right) & \text { (8) : damping coefficient }
\end{array}
$$


The values in Table 2 lead to the following numerical results:

$$
\begin{aligned}
& \mathrm{F}_{\mathrm{n}}=\frac{\omega_{\mathrm{n}}}{2 \pi}=9.5 \mathrm{MHz} \\
& \mathrm{z}=46.4
\end{aligned}
$$

The final form of equation (5) is therefore written at a frequency $\mathrm{F}$, taking into account that $\mathrm{z}>1$ :

$$
T_{i}=K_{i} \cdot \frac{\left(1+j \frac{F}{F_{j}}\right) \cdot\left(1+j \frac{F}{F_{k}}\right)}{\left(1+j \frac{F}{F^{\prime}}\right) \cdot\left(1+j \frac{F}{F^{\prime \prime}}\right)}
$$

where :

$$
\begin{aligned}
& \mathrm{F}_{\mathrm{i}, \mathrm{j}, \mathrm{k}}=\frac{1}{2 \pi \cdot \tau_{\mathrm{i}, \mathrm{j}, \mathrm{k}}} \\
& \mathrm{F}^{\prime}=\frac{\omega_{\mathrm{n}}}{2 \pi}\left(\mathrm{z}-\sqrt{\mathrm{z}^{2}-1}\right) \\
& \mathrm{F}^{\prime \prime}=\frac{\omega_{\mathrm{n}}}{2 \pi}\left(\mathrm{z}+\sqrt{\mathrm{z}^{2}-1}\right)
\end{aligned}
$$

Table 3 below provides information on the different cut-off frequencies that occur in each transfer function. We can observe that these extend over a very large frequency band.

\begin{tabular}{|c|c|c|c|c|}
\hline$F^{\prime}$ & $F^{\prime}$ & $F_{\text {outer-memb }}$ & $F_{\text {periplasm }}$ & $F_{\text {inner-memb }}$ \\
\hline $102 \mathrm{kHz}$ & $881 \mathrm{MHz}$ & $149 \mathrm{kHz}$ & $961 \mathrm{MHz}$ & $327 \mathrm{~Hz}$ \\
\hline
\end{tabular}

Table 3 - Cut-off frequencies occurring in the transfer functions expressed as in equation (11). Subscript $i$ refers to the layer on which the voltage is calculated and then divided by the total cell wall voltage, while subscripts $j$ and $k$ refer to the other layers. For example, if " $i$ " is "outer-layer", then " $j "$ is "periplasm" and "k" is "inner-layer".

Before finalizing the actual frequency analysis, it remains to provide the limit levels for each transfer function. Thus the low frequency limit of Ti results from a purely resistive voltage division, because the capacity of each layer has a much higher impedance than that of the corresponding resistance, while the high frequency limit is the dual case and results from a purely capacitive divider bridge. It follows: 


$$
\begin{aligned}
& \underset{F \rightarrow 0}{\lim _{F}\left(T_{i}\right)}=K_{i}=\frac{R_{i}}{R_{i}+R_{j}+R_{k}} \\
& \lim _{F \rightarrow \infty}\left(T_{i}\right)=\frac{C_{j} C_{k}}{C_{j} C_{k}+C_{i} C_{k}+C_{i} C_{j}}
\end{aligned}
$$

Table 4 summarizes the values in $\mathrm{dB}$ found for each of the layers:

\begin{tabular}{|c|c|c|c|}
\hline & Outer membrane & Periplasm & Inner membrane \\
\hline $\lim \left(\mathrm{T}_{\mathrm{i}, \mathrm{dB}}\right)$ & $-60 \mathrm{~dB}$ & $-147 \mathrm{~dB}$ & $8 \times 10^{-3} \mathrm{~dB} \approx 0 \mathrm{~dB}$ \\
\hline $\lim _{\mathrm{F} \rightarrow 0}\left(\mathrm{~T}_{\mathrm{i}, \mathrm{dB}}\right)$ & $-10,9 \mathrm{~dB}$ & $-21,7 \mathrm{~dB}$ & $-4 \mathrm{~dB}$ \\
\hline
\end{tabular}

Table 4 - Limit values of transfer functions for the three layers of the cell wall.

At this stage of the study it is already possible to predict some global behaviors. The periplasm behaves almost like a short circuit compared to other layers, due to its high electrical conductivity, and consequently no voltage develops there. The inner membrane, which has the lowest conductivity, recovers the entire voltage applied to the cell wall at low frequency.

Figures 6 to 8 provide the Bode diagrams of the three transfer functions, namely $\mathrm{T}_{\text {outer-memb, }}$, $\mathrm{T}_{\text {periplasm }}$ and $\mathrm{T}_{\text {inner-memb}}$, respectively, calculated in $\mathrm{dB}$ according to equation (11), from 10 $\mathrm{kHz}$ to $100 \mathrm{MHz}$.

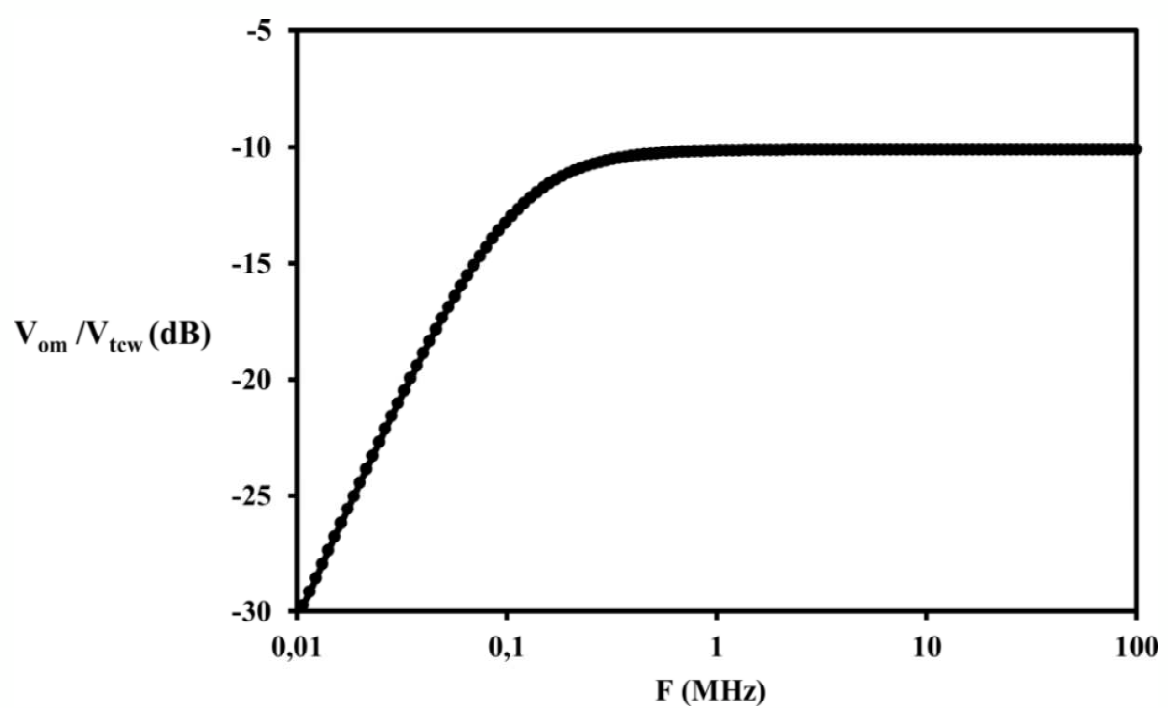

Figure 6 - Transfer function expressing in $\mathrm{dB}$ the ratio of the voltage on the outer membrane $\left(\mathrm{V}_{\text {om }}\right)$ to the total cell wall voltage $\left(\mathrm{V}_{\text {tcw }}\right)$. 


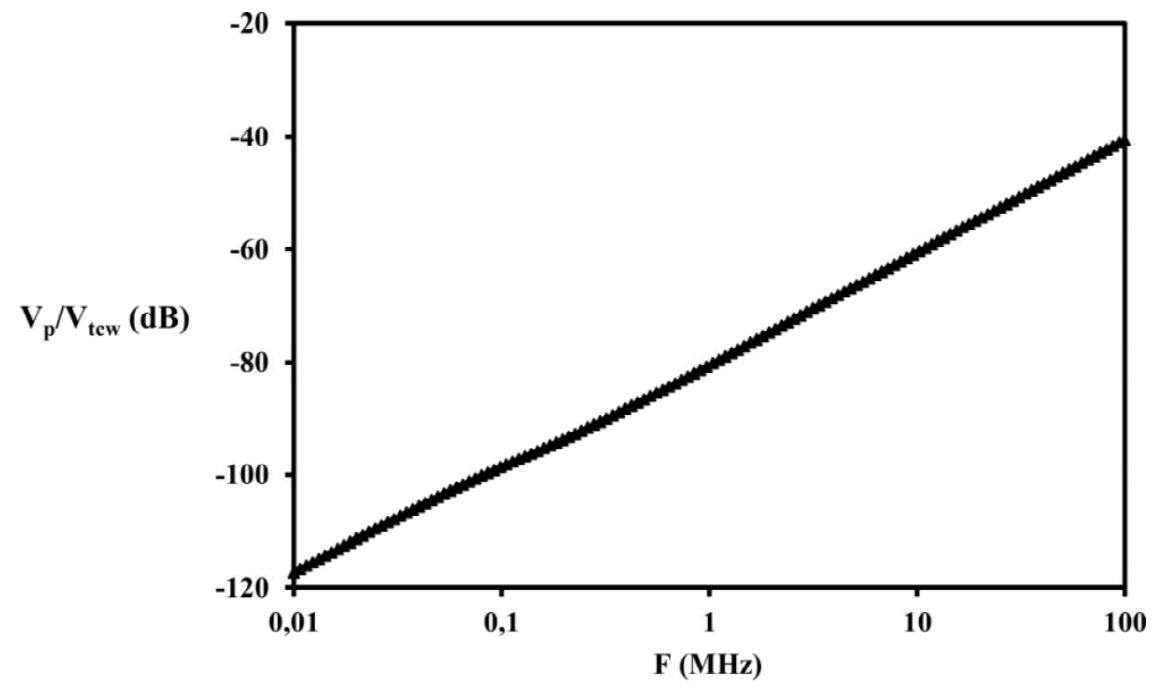

Figure 7 - Transfer function expressing in $\mathrm{dB}$ the ratio of the voltage on the periplasm $\left(\mathrm{V}_{\mathrm{p}}\right)$ to the total cell wall voltage $\left(\mathrm{V}_{\mathrm{tcw}}\right)$.

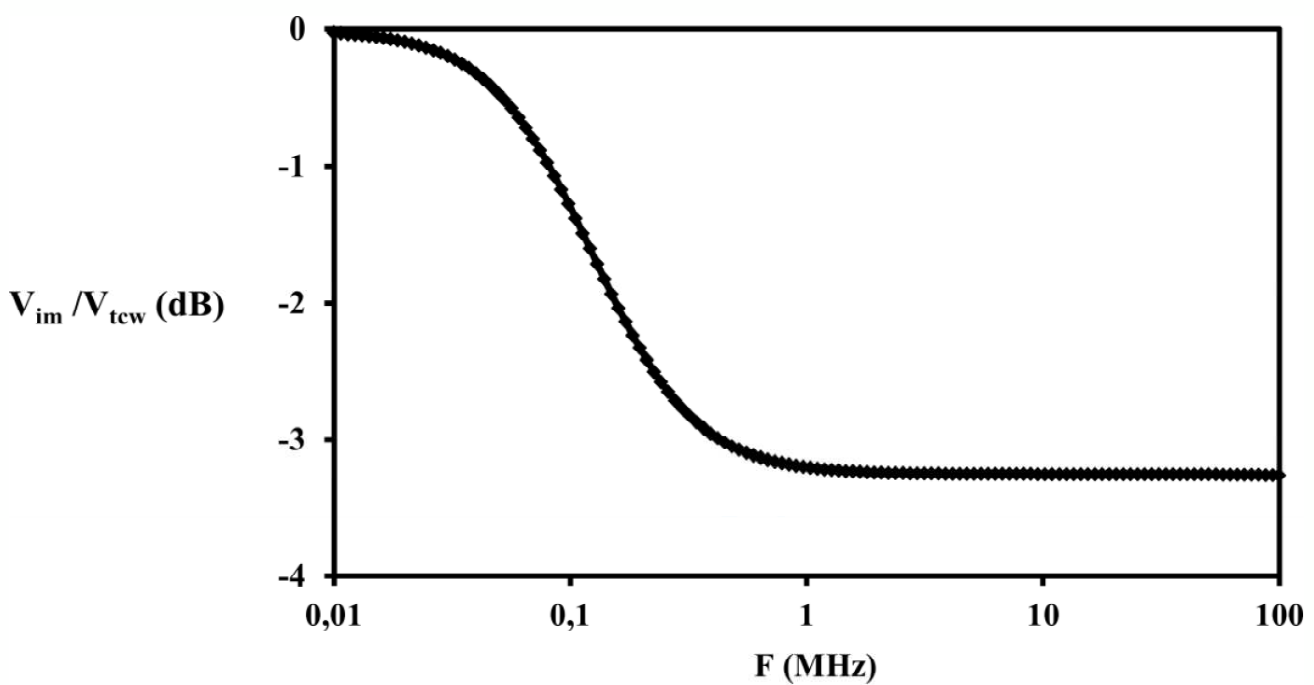

Figure 8 - Transfer function expressing in $\mathrm{dB}$ the ratio of the voltage on the inner membrane $\left(\mathrm{V}_{\mathrm{im}}\right)$ to the total cell wall voltage $\left(\mathrm{V}_{\mathrm{tcw}}\right)$.

The analysis of Figures 6 and 8 shows that the transfer functions for the inner membrane and outer membrane are practically constant above $1 \mathrm{MHz}$, while the one for the periplasm evolves with a constant slope in the studied range, with very low values as expected. This is explained by the combination of the slopes constituting the asymptotic Bode diagram and by the particular values of the cut-off frequencies mentioned in Table 3.

\section{Induced AC voltages on the cell wall sublayers}

The results of the COMSOL ${ }^{\mathrm{TM}}$ Multiphysics computation (Figures 3 and 4) combined with the calculation of the transfer functions (Figures 6 to 8), finally provide the induced voltage on each of the three sublayers of the cell wall, when an external electric field of $1 \mathrm{~V} / \mathrm{cm}$ is applied, in both longitudinal and transversal orientations. The studied frequency range is limited to the validity domain for the COMSOL model [Xavier et al., 2017], i.e. from $1 \mathrm{MHz}$ to $20 \mathrm{MHz}$. 
- Longitudinal orientation

The result for a longitudinal orientation is given in Figures 9 and 10, corresponding respectively to the $\mathrm{P}$ poles and the intermediate points I of the bacterial cell (see Figure 2). The amplitude of the voltages developed on each layer is expressed in $\mathrm{dB}_{\mu \mathrm{V}}$ according to the relationship:

$$
\mathrm{V}_{\mathrm{dB} \mu \mathrm{V}}=20 \log _{10}\left(\frac{\mathrm{V}_{\mathrm{m}}}{10^{-6}}\right)
$$

where $\mathrm{V}_{\mathrm{m}}$ is the amplitude in Volts.

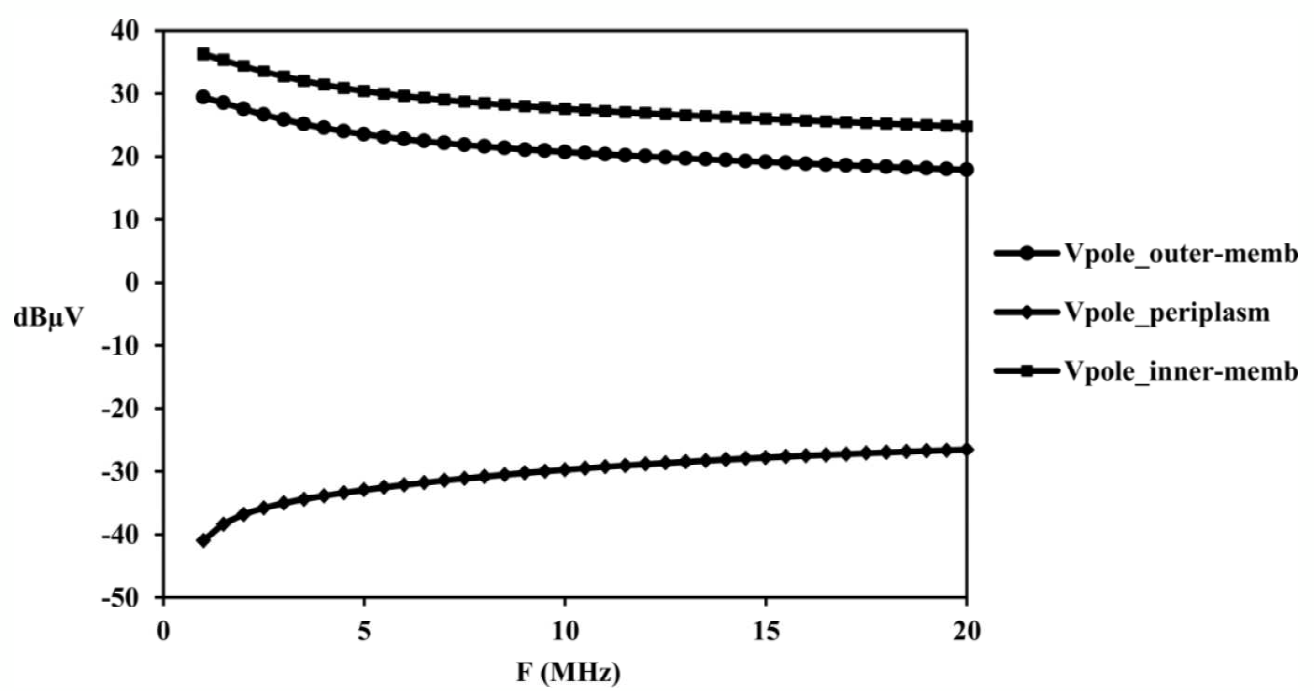

Figure 9 - Amplitude in $\mathrm{dB}_{\mu \mathrm{V}}$ of the $\mathrm{AC}$ voltages developed at the $\mathrm{P}$ poles of the bacterial cell (see Figure 2) on each of the three layers constituting the cell wall (outer-membrane $\bullet$, periplasm $\bullet$, innermembrane $\mathbf{a})$, when applying longitudinally an external electric field of amplitude $1 \mathrm{~V} / \mathrm{cm}$.

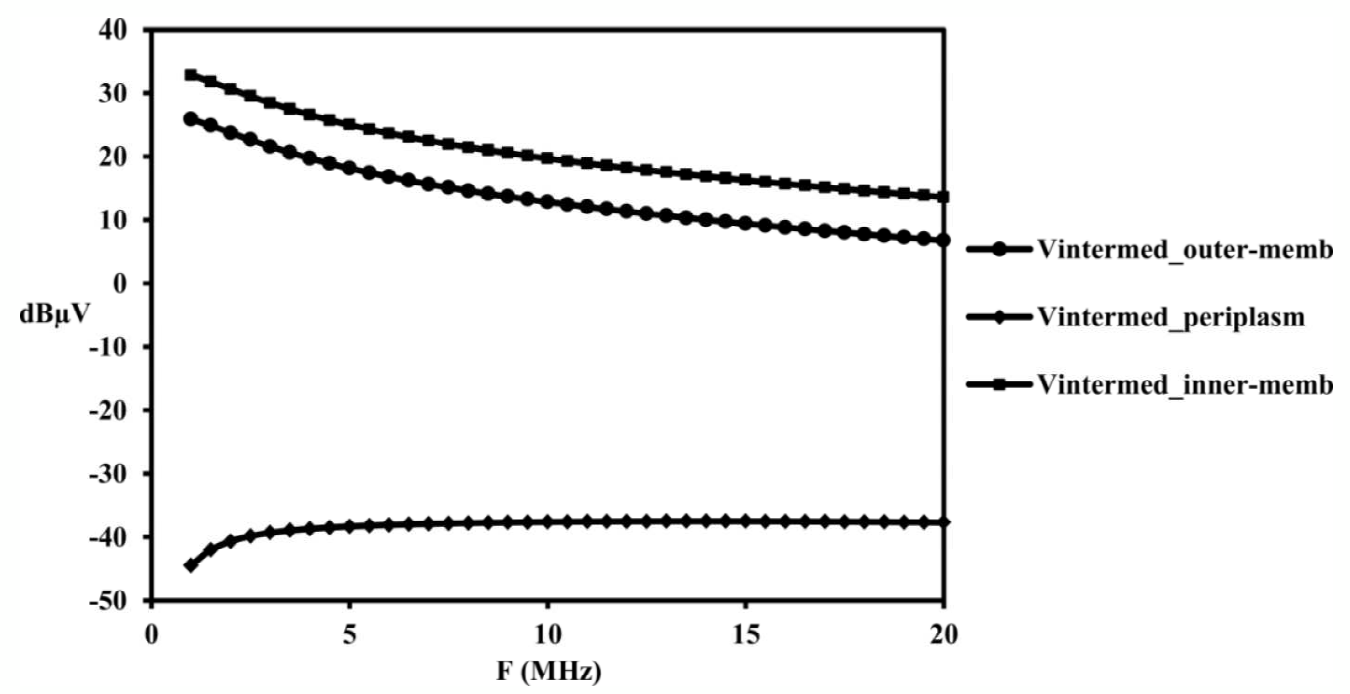

Figure 10 - Amplitude in $\mathrm{dB}_{\mu \mathrm{V}}$ of the $\mathrm{AC}$ voltages developed at the intermediate points I of the bacterial cell (see Figure 2) on each of the three layers constituting the cell wall (outer-membrane $\bullet$, periplasm $\bullet$, inner-membrane $\mathbf{~}$ ), when applying longitudinally an external electric field of amplitude $1 \mathrm{~V} / \mathrm{cm}$.

It can be seen that the voltage developed on the inner membrane (phospholipidic) is dominant, while that on the outer membrane (LPS) is about $7 \mathrm{~dB}$ lower (i.e. multiplied by 
0.45 ) at both points $\mathrm{P}$ and $\mathrm{I}$, over the full studied frequency range. The voltage on the periplasm layer is negligible at any point, as already explained in the previous paragraph.

It must be kept in mind here that the voltage at the middle points $M$ is zero on each of the layers, with a longitudinal orientation of the electric field.

- Transversal orientation

Results for transversal orientation of electric field are shown in Figures 11 and 12, corresponding respectively to points $\mathrm{M}$ and I (Fig. 2), the voltage at points $\mathrm{P}$ being now zero.

These results revealed a similar behavior to that observed with longitudinal orientation, except that the voltage decreases slower with frequency.

Indeed, with longitudinal orientation, the voltage on the inner membrane decreases at intermediate point I from $33 \mathrm{~dB}_{\mu \mathrm{V}}$ to $14 \mathrm{~dB}_{\mu \mathrm{V}}$ (i.e. from $44 \mu \mathrm{V}$ to $5 \mu \mathrm{V}$ in a linear scale) when the frequency changes from $1 \mathrm{MHz}$ to $20 \mathrm{MHz}$, while with transversal orientation it changes at the same point from $29 \mathrm{~dB}_{\mu \mathrm{V}}$ to $26 \mathrm{~dB}_{\mu \mathrm{V}}$ (i.e. $27 \mu \mathrm{V}$ to $20 \mu \mathrm{V}$ ) on the same frequency excursion.

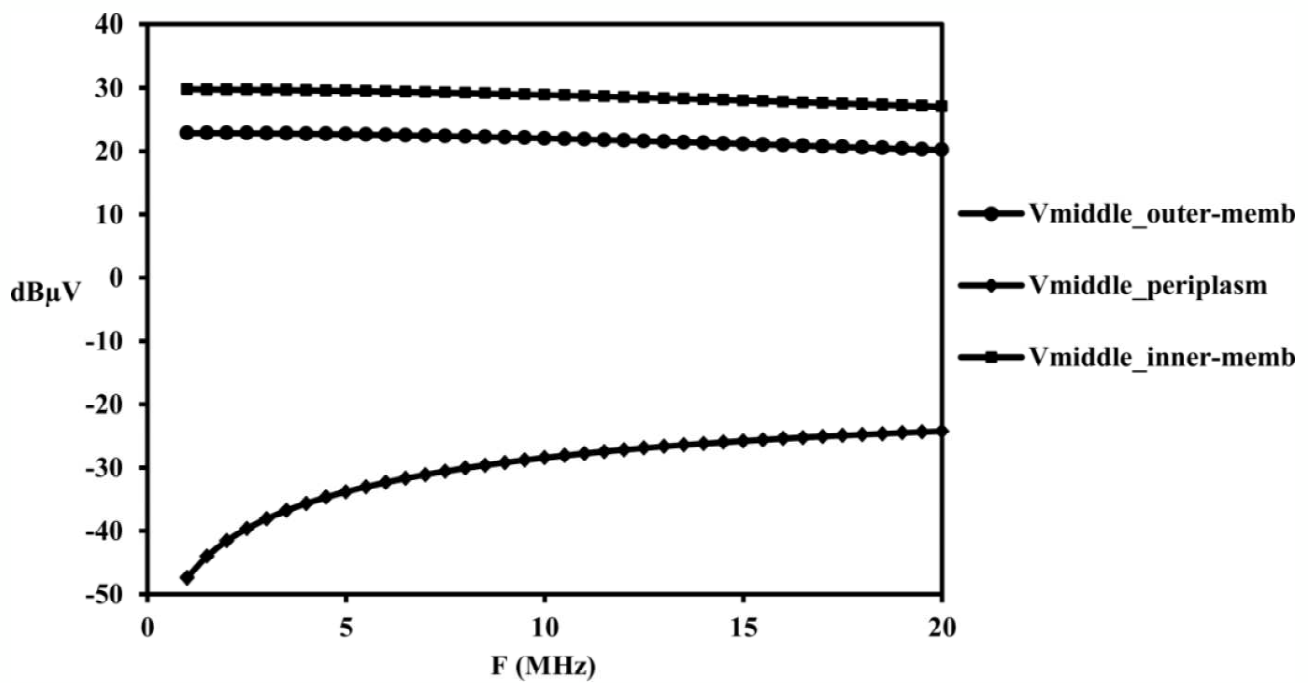

Figure 11 - Amplitude in $\mathrm{dB}_{\mu \mathrm{v}}$ of the $\mathrm{AC}$ voltages developed at the middle points $\mathrm{M}$ of the bacterial cell (see Figure 2) on each of the three layers constituting the cell wall (outer-membrane $\bullet$, periplasm $\downarrow$, inner-membrane $\mathbf{\square})$, when applying transversally an external electric field of amplitude $1 \mathrm{~V} / \mathrm{cm}$. 


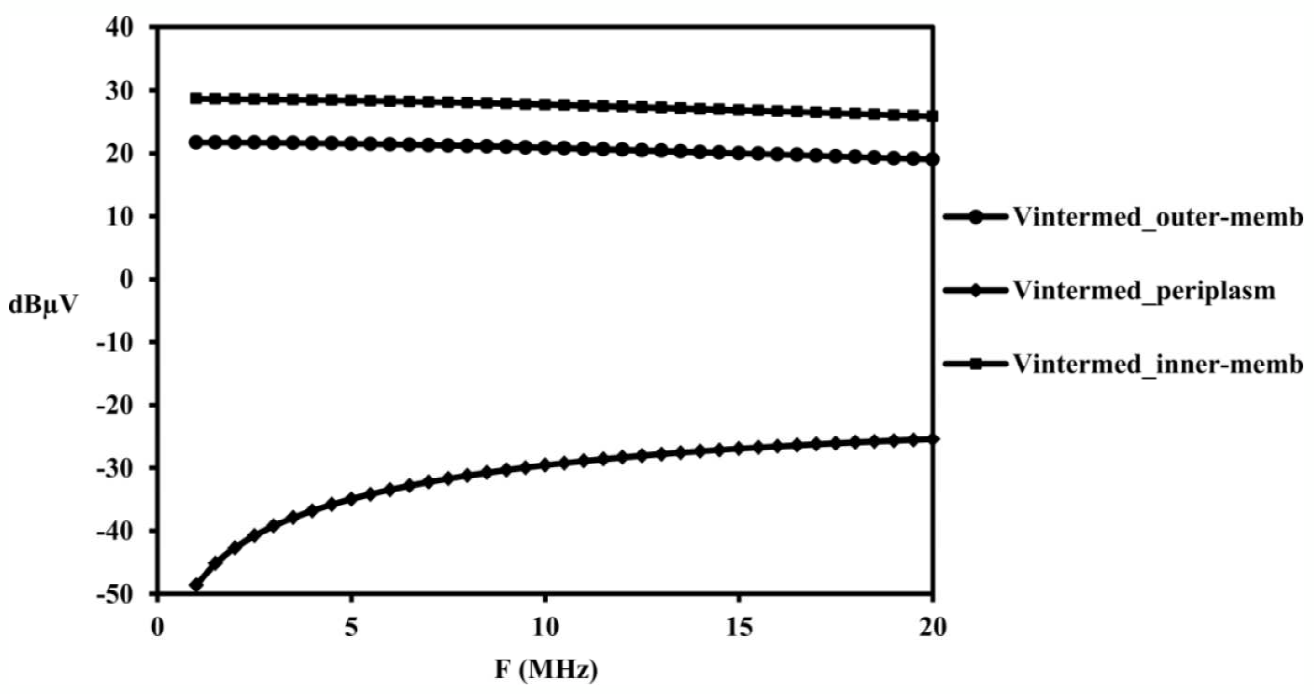

Figure 12 - Amplitude in $\mathrm{dB}_{\mu \mathrm{v}}$ of the $\mathrm{AC}$ voltages developed at the intermediate points $\mathrm{I}$ of the bacterial cell (see Figure 2) on each of the three layers constituting the cell wall (outer-membrane $\bullet$, periplasm $\bullet$, inner-membrane $\mathbf{~})$, when applying transversally an external electric field of amplitude $1 \mathrm{~V} / \mathrm{cm}$.

\section{What membrane proteins could potentially be affected?}

This short section aims to show how this study could be used as a working tool in an attempt to establish a link between macroscopically observed bacterial growth inhibition and the biological processes under control of certain membrane proteins, which could be affected by the application of an external electric field, as a result of a possible destabilization of these proteins [Kell et al., 1985].

The information necessary to conduct this reflection could be organized according to two inputs, namely the biological function associated with a protein on the one hand, and the location of the latter in the membrane on the other hand. Below are some of the elements that can be said on each of the three layers.

\section{- Periplasm}

First of all, proteins [Beacham et al., 1979] or functions located in the periplasm should be classified as the least likely candidates to explain the growth inhibition. Even if disruption of some functions (see for example [Mergulhao et al., 2007]) in the periplasm could be assumed to cause growth inhibition, this effect could not be produced by an external electric field, according to our conclusions that the induced voltage on the periplasmic layer is almost negligible compared to the voltages developed on the other layers.

\section{- Inner phospholipid layer}

Functions controlled by proteins located in the inner layer are subject to the highest $\mathrm{AC}$ voltage. Consequently they are most likely to be impacted, and their dysfunction could explain the growth inhibition induced by an alternating electric field, without the addition of a biocidal agent, as reported in the literature [Giladi et al., 2008]. 
It may be relevant to examine those related to the metabolism of the bacterium, as part of the chemiosmotic process: cell respiration, proton pumps, ATP synthase, etc..

The respiratory chain, also called Electron Transfer Chain (ETC), is the seat, in the phospholipid membrane, of successive redox operations, whose redox potential decreases until the terminal electron acceptor is reached. In E.coli, the elements of this chain are namely flavoprotein (FMN, FAD), cytochromes, iron-sulfur proteins and quinones.

Some investigations have demonstrated the modification by an external electric field of the redox potential, in particular that of the cytochrome c [Rivas et al., 2005]. Even if the changes observed so far require a much higher level of field than that of our study, these works constitute an interesting line of work. Indeed, the scenario whereby two successive elements of the ETC chain would undergo an inversion of the redox potential gradient would lead to a blockage of the respiratory chain, and growth inhibition as a consequence.

Another line of investigation concerns protein complexes in charge of ensuring regulation, such as cytoplasmic $\mathrm{pH}$ homeostasis. Thus the $\mathrm{NhaA} \mathrm{Na} / \mathrm{H}^{+}$antiporter, partially located in the phospholipid membrane, performs the dual function of $\mathrm{pH}$ sensor and actuator [Hunte et al. , 2005]. Furthermore it has been proven that mitosis can be disrupted if $\mathrm{pH}$ homeostasis fails [Zilberstein et al., 1984], which could be another explanation for the inhibition of growth in a bacterial population: bacteria grow and lengthen but can no longer reproduce by cell division.

\section{- Outer LPS (lipopolysaccharide) layer}

The induced $\mathrm{AC}$ voltage developed on the outer layer is certainly lower than in the inner layer, but it remains in the same order of magnitude. It could therefore also be expected that the expression of proteins in this layer would be affected.

Some of them control the transfer of biocidal substances between the exterior and interior of the cell, and must also be studied, even if this paper is essentially focused on electricidal effects in the absence of external biocides.

This is the case, for example, for porins located in the outer membrane, such as AcrAB Tolc which stops the extraction of antibiotics from the cell when disrupted [Gilardi et al., 2017]. Another similar example is the water porin $\mathrm{OmpF}$, which can be an entry point for antibiotics [Niramitranon Jitti et al., 2016]. In all these cases growth inhibition effect can be enhanced by the AC electric field, but the use of a biocide in the medium is required.

Other complexes located in the outer layer have multiple roles, such as drug resistance, combined with $\mathrm{pH}$ homeostasis, with the consequences explained above. This was revealed with E. coli BW25113 strain [Holdsworth et al, 2013].

\section{Discussion}

The theoretical results presented here, and all subsequent speculation, are based on models derived from extraction methods from experimental data, namely impedance spectroscopy and the 3-shell model [Bai et al, 2006], [Xavier et al, 2017]. As stated at the beginning of this article, it is important to remember what were the experimental conditions, and what are the adjustment variables and the variables set in the extraction method.

Thus the numerical value of the electrical conductivity of a layer, which is used in the 3-shell method, represents a spatially averaged value. But how does it change when moving from an 
area where no protein is anchored, to another area where the membrane is "loaded" by a protein or by a transporter? How can we model the membrane region near a transporter, knowing that it contains ions in the process of passive or active diffusion?

This problem has been extensively studied in the literature [Hodgkin et al., 1952], [Hille, 1992], and models have been established, most often non-linear, or establishing current-voltage characteristics of these transporters. If an equivalent circuit of the type shown in Figure 13 is used, where each source represents the Nernst-Planck potential associated with a particular ionic species, it may be easy, after a small signal linearization operation, to extract a dynamic resistance from it, modeling the membrane region undergoing a variable voltage.

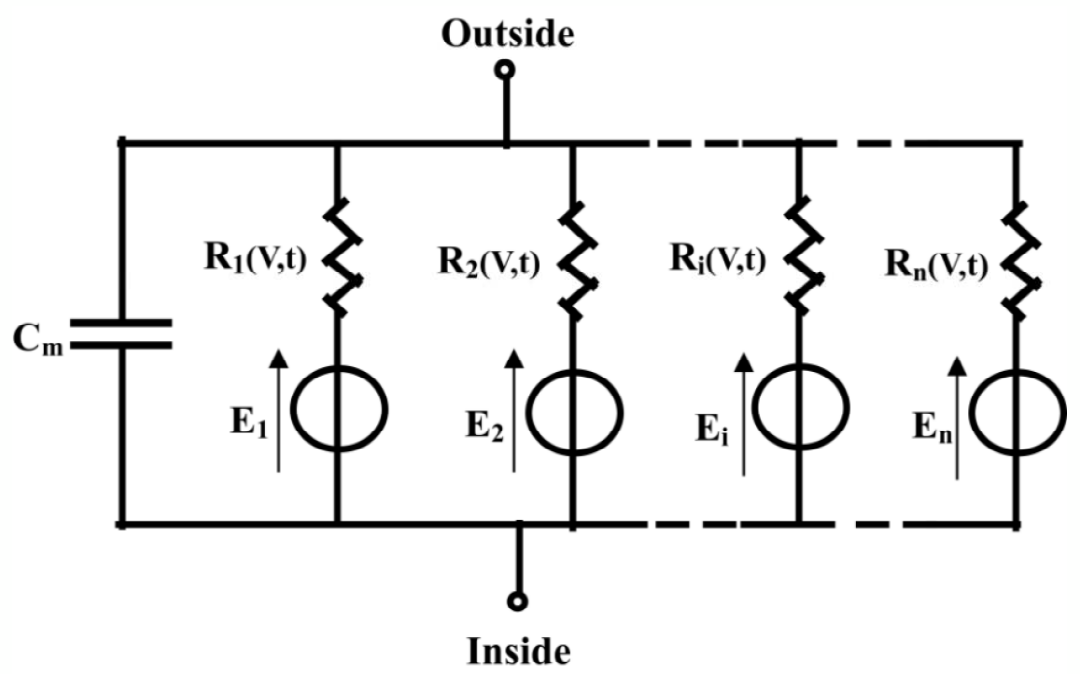

Figure 13 - Proposal of the general structure of a surface membrane element with ionic exchanges. This model, inspired by the HHK (Hodgkin, Huxley \& Katz) theory, is non-linear a priori, the resistors $\mathrm{R}_{\mathrm{i}}(\mathrm{V}, \mathrm{t})$ being dependent on the voltage at their terminals and time [Hodgkin et al, 1952].

But this equivalent circuit may no longer be valid in high frequency. The used model must be able to correctly describe the response of charges in presence, whether free or linked, to a high frequency electric field stimulus. The implementation under $\mathrm{COMSOL}^{\mathrm{TM}}$ Multiphysics of a membrane zone loaded by a carrier will be the subject of a subsequent study.

\section{Conclusion and perspectives}

In the context of understanding the underlying biological causes of the electricidal effect inducing bacterial growth inhibition, the overall $\mathrm{AC}$ voltage induced by an external electric field was calculated on the cell wall of a model of the gram-negative bacteria $E$. coli, suspended in a physiological serum. With an amplitude field of $1 \mathrm{~V} / \mathrm{cm}$, the cell wall voltage is found to be much lower (a few tens of $\mu \mathrm{V}$ ) than the transmembrane resting DC potential.

The investigations therefore focused on the detailed distribution of this voltage on each of the three layers constituting the cell wall. Revealing that the induced voltage develops mainly on the inner and outer layers, and very little on the periplasm, this work opens the way to propose candidate proteins whose disruption could lead to growth inhibition.

However, the analysis must be extended in a further study. Indeed, the cell wall was probed in the direction of its thickness. Voltages and electric fields developing in a direction parallel to the membrane surface should also be analysed, because conformational changes of proteins 
subjected to longitudinal electrical stresses may be important and induce significant consequences, since it differs slightly from the huge transversal stress they already undergo in normal circonstances due to the resting potential. In addition, the problem of the fine modeling of membrane regions in the area around the different structures where ionic flows are located (transporters, channels, etc.) must be investigated taking into account the biological mode of diffusion (active or passive) as well as the mobility of electrical charges at high frequencies.

\section{References}

Abo-Neima S.E., Khedr Y.I., Kotb M.M., Elhoseiny A., Motaweh H.A. « Control of metabolic activities of E.coli and S. aureus bacteria by Electric Field at Resonance Frequency in vitro study » International Journal of Engineering And Science Vol 6, Issue 9, pp 13-25, oct 2016

Bai W., Zhao K.S. and Asami K.

« Dielectric properties of E. coli cell as simulated by the three-shell spheroidal model» Biophysical Chemistry vol. 122, 2006, pp136-142

Beacham I.R.

«Periplasmic Enzymes in Gram-negative Bacteria »

International Journal of Biochemistry vol. 10, issue 11, 1979, pp877-883

Bot C.D. and Prodan C.

"Quantifying the membrane potential during E. coli growth stages»

Biophysical Chemistry Vol. 146, 2010, pp133-137

Del Pozo J.L., Rouse M.S., Mandrekar J.N., Steckelberg J.M.and R. Patel R.

«The Electricidal Effect: Reduction of Staphylococcus and Pseudomonas Biofilms by Prolonged Exposure to Low-Intensity Electrical Current »

Antimicrob. Agents Chemother., vol. 53, Issue 1, jan 2009, pp. 41-45

Giladi M, Porat Y, Blatt A, Wasserman Y, Kirson ED, Dekel E, Palti Y.

"Microbial growth inhibition by alternating electric fields"

Antimicrobial Agents Chemotherapy 52(10), 2008, pp3517-3522.

Giladi M., Porat Y., Blatt A., Shmueli E., Wasserman Y., Kirson E.D., Palti Y.

« Microbial Growth Inhibition by Alternating Electric Fields in Mice with Pseudomonas aeruginosa Lung Infection »

Antimicrobial Agents and Chemotherapy Vol. 54, Issue 8, Aug 2010, pp 3212-3218,

Gilardi A., Bhamidimarri S.P., Brönstrup M., Bilitewski U, Marreddy R.K.R., Pos K.M., Benier L., Gribbon P., Winterhalter M., Windshügel B.

«Biophysical characterization of E-coli TolC interaction with the known blocker hexaamminecobalt »

Biochimica et Biophysica Acta Vol. 1861 Issue: 11, Part: A Nov 2017, pp 2702-2709

Hille B.

« Ionic Channels of Excitable Membranes (2nd ed.)»

Ed Sunderland, MA: Sinauer, 1992 
Hodkin A.L., Huxley A.F., Katz B.

«Measurement of current-voltage relations in the membrane of the giant axon of Loligo » J. Physiol. Vol. 116, 1952, pp 424-448.

Holdsworth S. R. \& Law C.J.

« Multidrug resistance protein MdtM adds to the repertoire of antiporters involved in alkaline $\mathrm{pH}$ homeostasis in Escherichia coli »

BMC Microbiology, vol. 13, 113, 2013, pp 1-19

(see also cited articles)

Hunte C., Screpanti E., Venturi M., Rimon A., Padan E. \& Michel H.

« Structure of a Na$~^{+} / \mathrm{H}^{+}$antiporter and insights into mechanism of action and regulation by $\mathrm{pH} »$

Nature, vol 435, 30, june 2005, pp1197-1202

Jain S., Sharma A., Basu B.

«Vertical electric field induced bacterial growth inactivation on amorphous carbon electrodes $\gg$

Carbon 81 (2015) pp 193-202

Kell D.B. \& and Harris C.M.

« Dielectric Spectroscopy and Membrane Organisation»

Journal of Biolelectricity Vol $4 \mathrm{~N}^{\circ} 2,1985$ pp317-348

Mergulhao F.J, Monteiro GA.

« Analysis of factors affecting the periplasmic production of recombinant proteins in Escherichia coli »

Journal of Microbiology and Biotechnology Vol 11, Issue 8, Aug 2007, pp1236-1241

Niramitranon Jitti, Sansom Mark SP, Pongprayoon Prapasiri

"Why do the outer membrane proteins OmpF from E. coli and OprP from P. aeruginosa refer trimers? Simulation studies »

Journal of Molecular Graphics and Modelling 65 (2016) 1-7

Rivas L., Soares C.M., Baptista A.M., Simaan J. ,Di Paolo R.E, Murgida D.H. and Hildebrandt P.

« Electric-Field-Induced Redox Potential Shifts of Tetraheme Cytochromes c3 Immobilized on Self-Assembled Monolayers: Surface-Enhanced Resonance Raman Spectroscopy and Simulation Studies »

Biophysical Journal Vol 88, June 2005, pp 4188-4199

Vetterli S.U., Zerbe K., Müller M., Urfer M., Mondal M., Wang S.Y., Moehle K., Zerbe O., Vitale A., Pessi G., Eberl L., Wollscheid B., Robinson J.A.

«Thanatin targets the intermembrane protein complex required for lipopolysaccharide transport in Escherichia coli »

Sci Adv 14 Nov 2018, Vol. 4, no. 11

Xavier P, Rauly D., Chamberod E., Martins J.M.F.

« Theoretical Evidence of Maximum Intracellular CurrentsVersus Frequency in an Escherichia coli Cell Submitted toAC Voltage »

Bioelectromagnetics 38: pp213-219 (2017)

Zilberstein D., Agmon V., Schuldiner S. and Padan E.

« Escherichia coli intracellular $\mathrm{pH}$, membrane potential, and cell growth » 
J. Bacteriol. Vol 158, 1984, pp246-252

Zituni D., Schutt-Gerowitt H., Kopp M., Kronke M., Addicks K., Hoffmann C., Hellmich M., Faber F., Niedermeier W.

« The growth of Staphylococcus aureus and Escherichia coli in low-direct current electric fields $\gg$

International Journal of Oral Science Vol. 6, Issue 1, pp 7-14, March 2014 
1

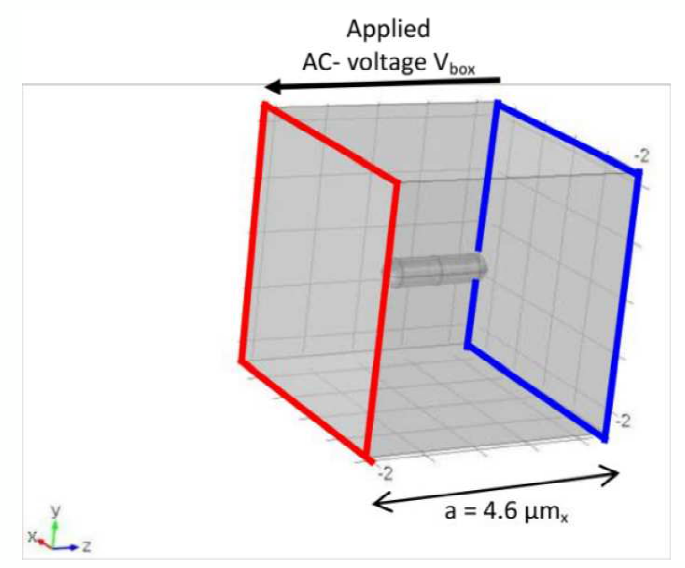

Figure 1-a

Elementary box with a single longitudinally excited cell, numerically studied using COMSOL ${ }^{\mathrm{TM}}$ multiphysics

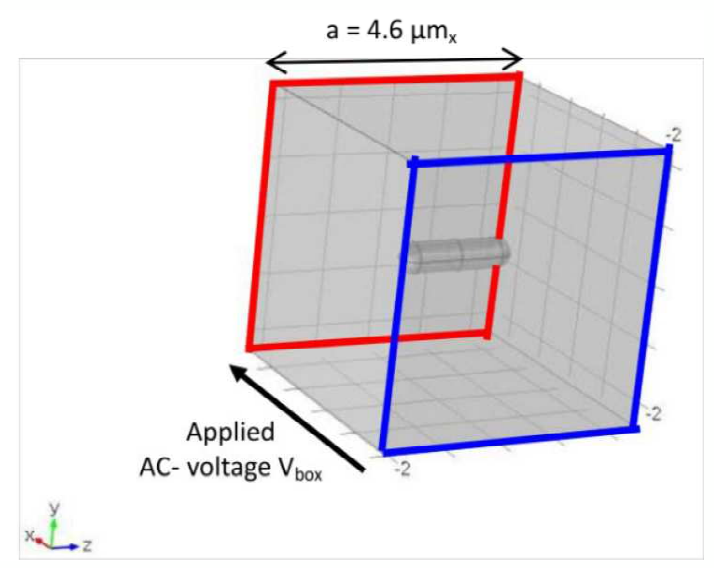

Figure 1-b

Elementary box with a single transversally excited cell, numerically studied using $\mathrm{COMSOL}^{\mathrm{TM}}$ multiphysics

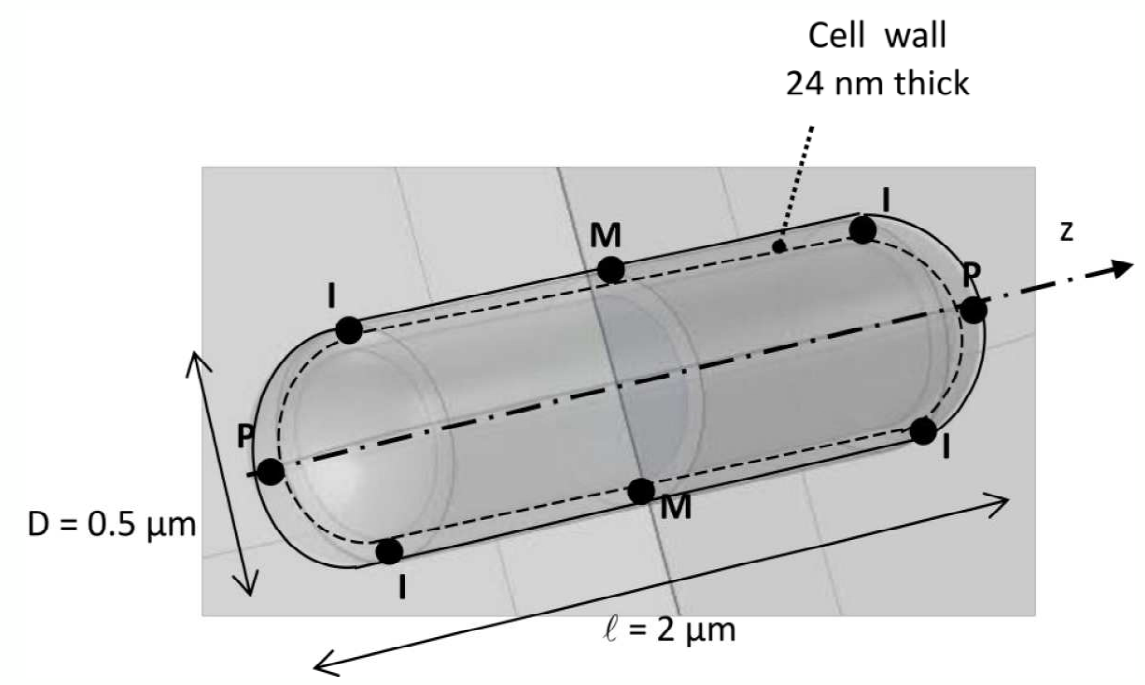

Figure 2 - COMSOL model of Escherichia coli with equivalent monolayer cell wall. The induced transmembrane AC voltage is calculated at the points marked respectively $\mathbf{P}$ (pole), $\mathbf{M}$ (middle) and $\mathbf{I}$ (intermediate). 


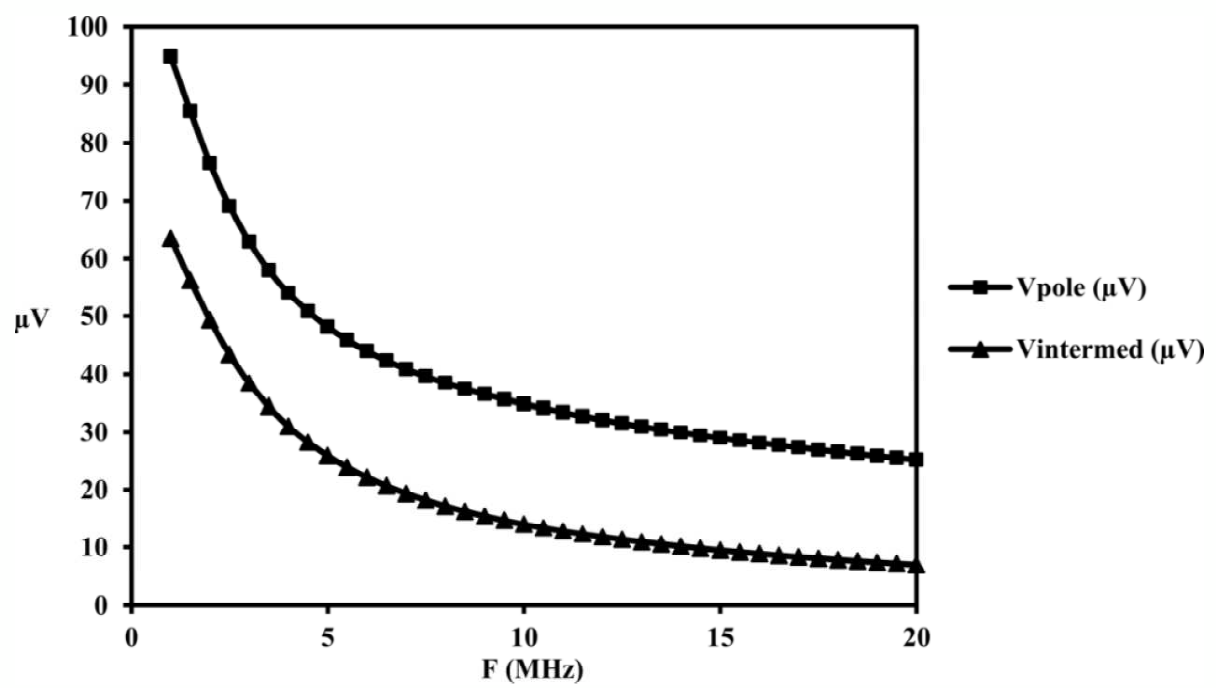

Figure 3 - Computed transmembrane AC voltage with a longitudinally applied electric field of amplitude $1 \mathrm{~V} / \mathrm{cm}$, at points $\mathrm{P}$ (poles) $(\boldsymbol{\bullet})$ and I (intermediate) $(\mathbf{\Delta})$ visibles on figure 2 . Voltage at middle points $\mathrm{M}$ is zero.

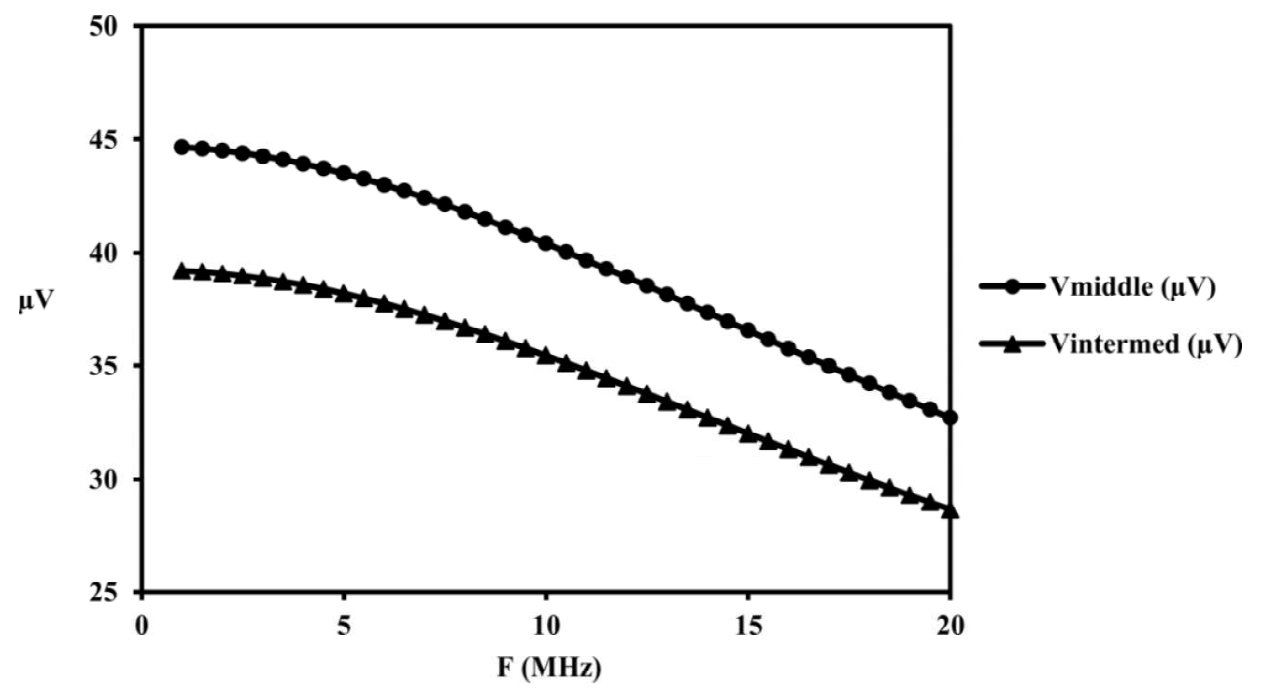

Figure 4 - Computed transmembrane AC voltage with a transversally applied electric field of

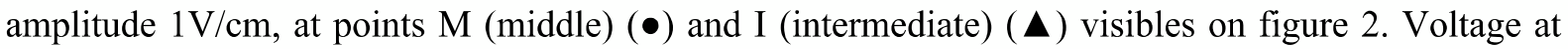
poles $\mathrm{P}$ is zero.

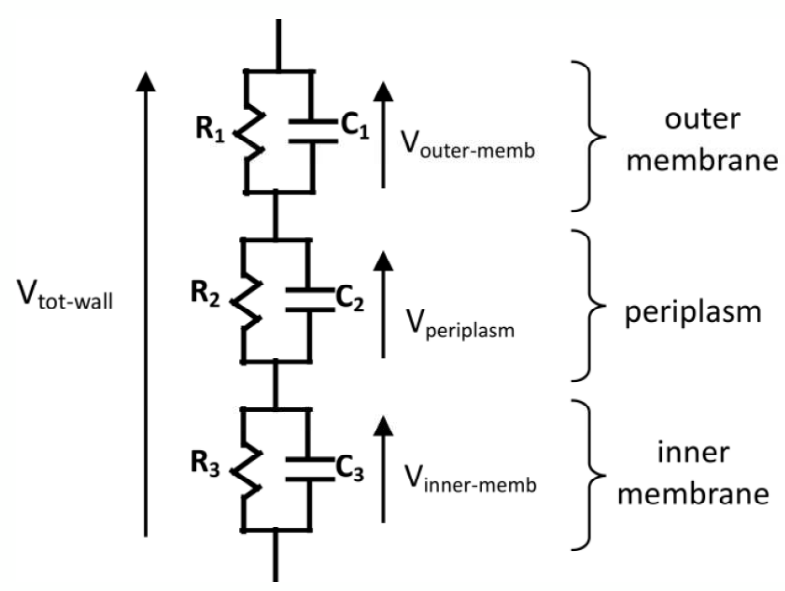


Figure 5 - Equivalent electrical circuit of a unit area of the Gram-negative cell wall, detailing each sublayer.

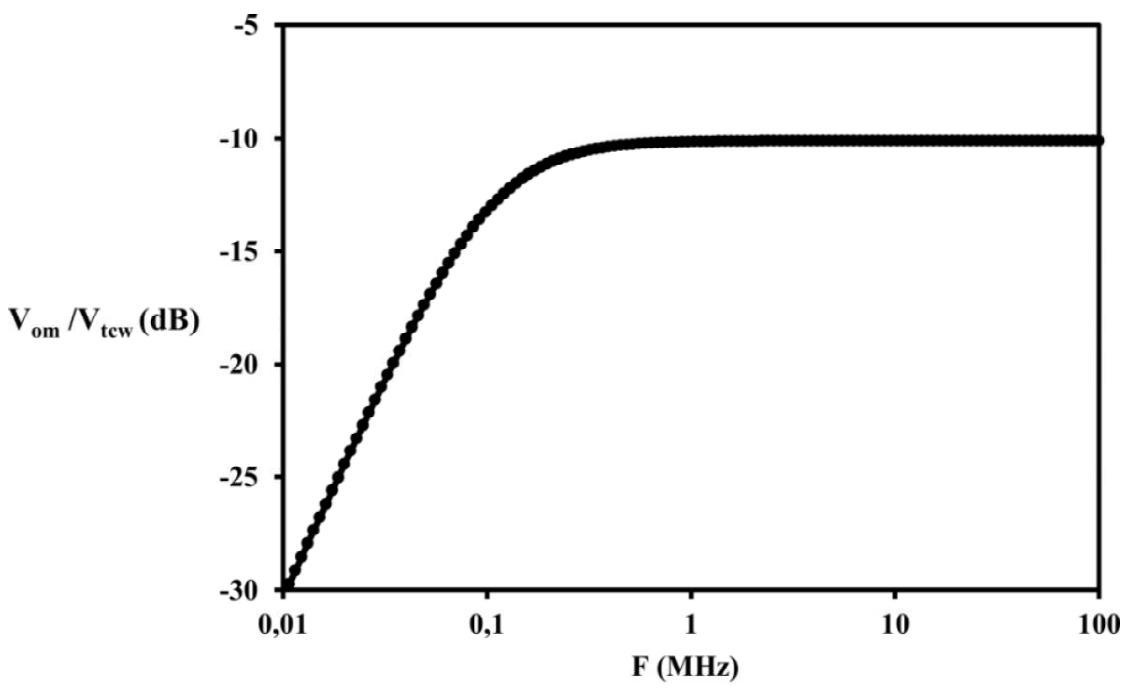

Figure 6 - Transfer function expressing in $\mathrm{dB}$ the ratio of the voltage on the outer membrane $\left(\mathrm{V}_{\text {om }}\right)$ to the total cell wall voltage $\left(\mathrm{V}_{\mathrm{tcw}}\right)$.

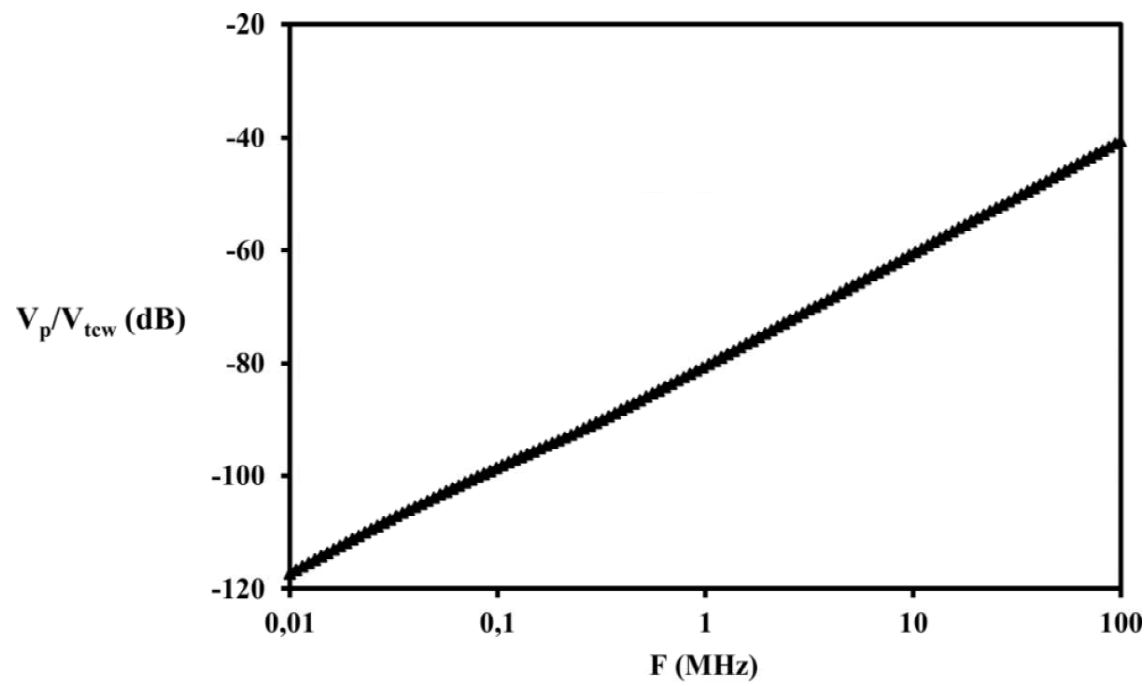

Figure 7 - Transfer function expressing in $\mathrm{dB}$ the ratio of the voltage on the periplasm $\left(\mathrm{V}_{\mathrm{p}}\right)$ to the total cell wall voltage $\left(\mathrm{V}_{\text {tcw }}\right)$. 


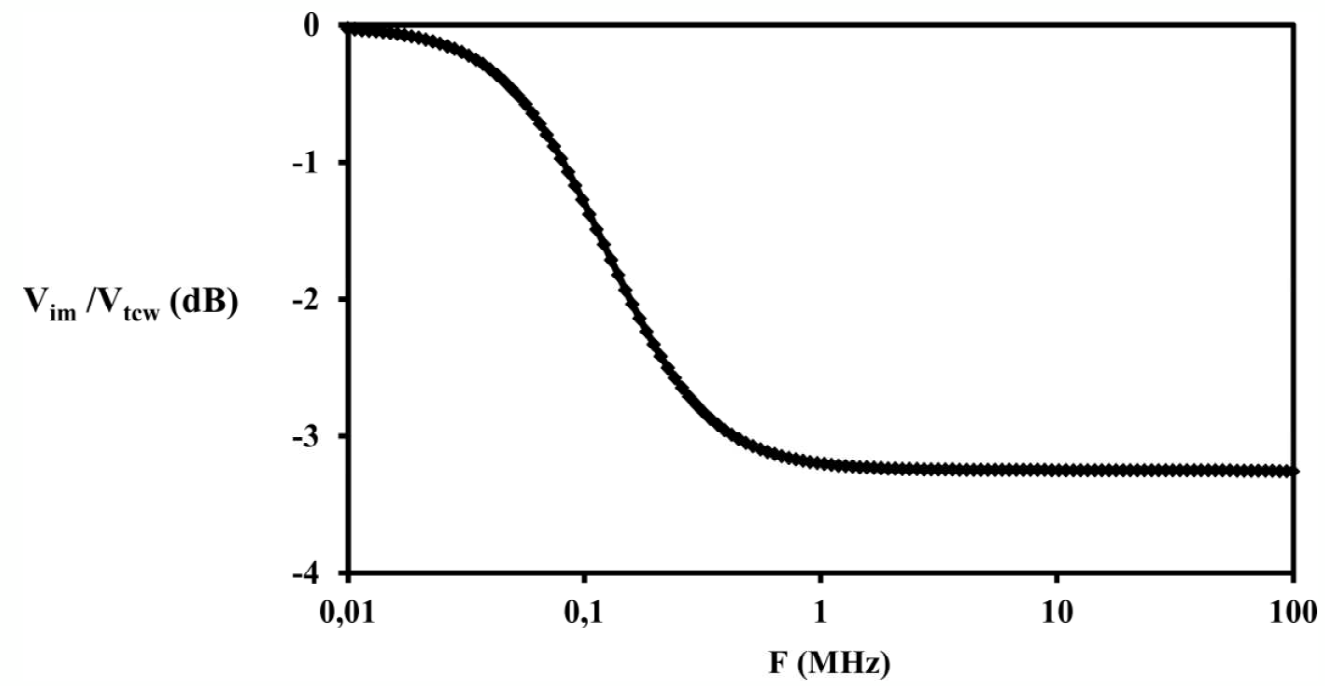

Figure 8 - Transfer function expressing in $\mathrm{dB}$ the ratio of the voltage on the inner membrane $\left(\mathrm{V}_{\mathrm{im}}\right)$ to the total cell wall voltage $\left(\mathrm{V}_{\text {tcw }}\right)$.

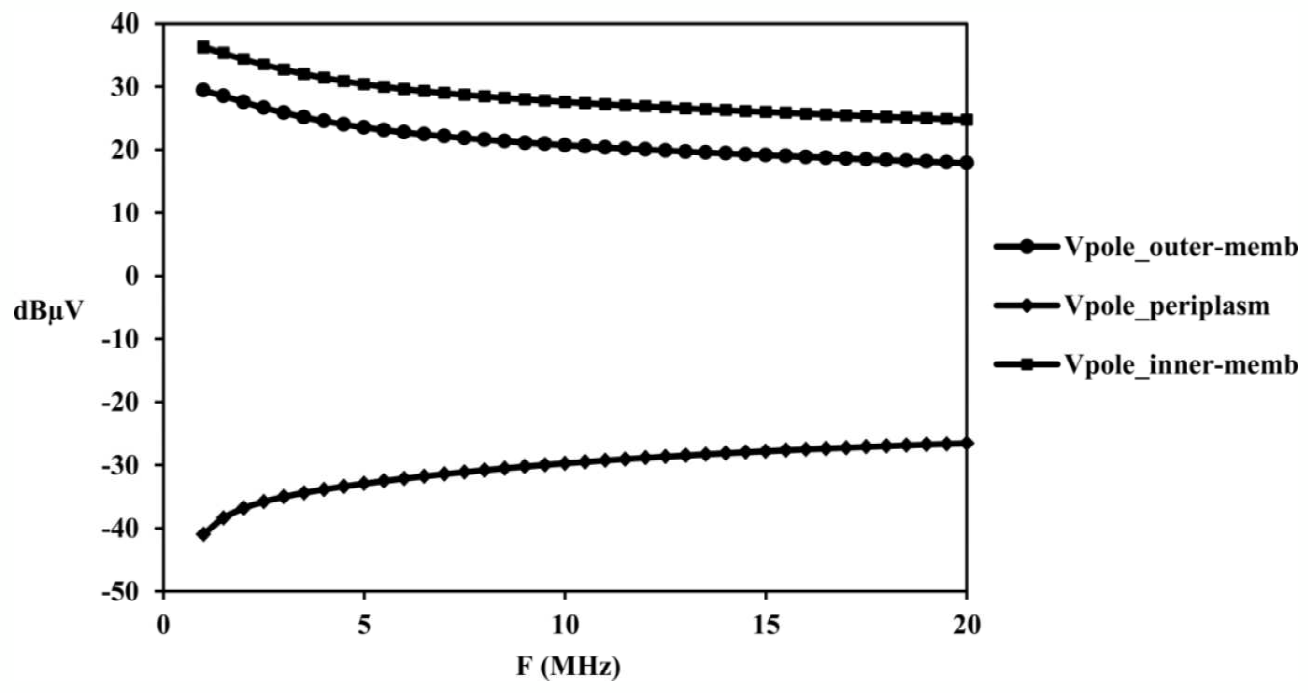

Figure 9 - Amplitude in $\mathrm{dB}_{\mu \mathrm{V}}$ of the $\mathrm{AC}$ voltages developed at the $\mathrm{P}$ poles of the bacterial cell (see Figure 2) on each of the three layers constituting the cell wall (outer-membrane $\bullet$, periplasm $\bullet$, innermembrane $\mathbf{m})$, when applying longitudinally an external electric field of amplitude $1 \mathrm{~V} / \mathrm{cm}$.

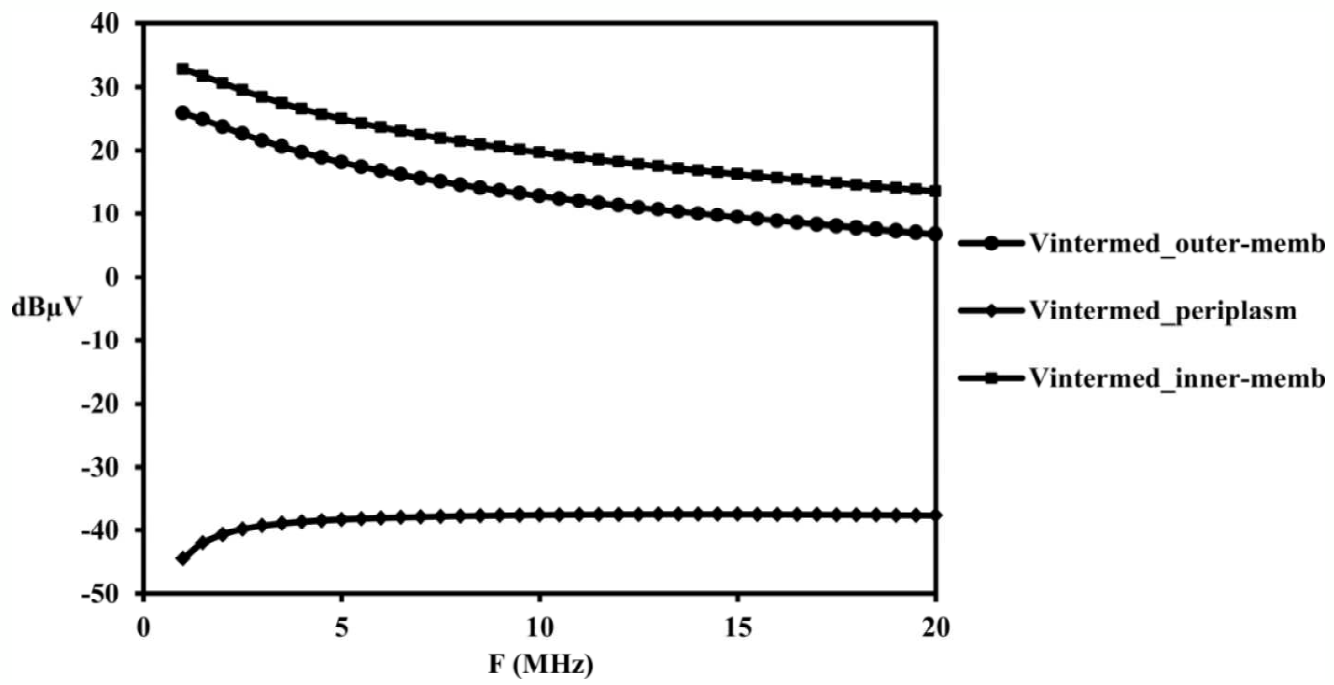


Figure 10 - Amplitude in $\mathrm{dB}_{\mu \mathrm{V}}$ of the $\mathrm{AC}$ voltages developed at the intermediate points $\mathrm{I}$ of the bacterial cell (see Figure 2) on each of the three layers constituting the cell wall (outer-membrane $\bullet$, periplasm $\bullet$, inner-membrane $\mathbf{~}$ ), when applying longitudinally an external electric field of amplitude $1 \mathrm{~V} / \mathrm{cm}$.

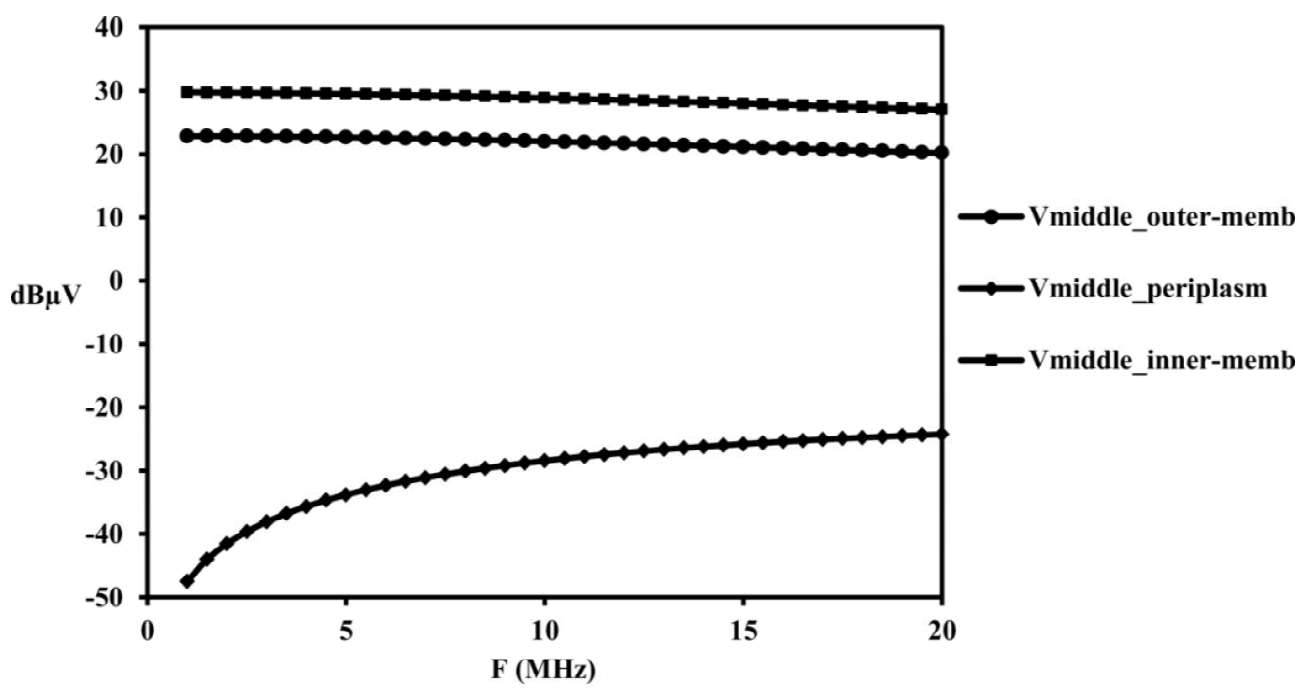

Figure 11 - Amplitude in $\mathrm{dB}_{\mu \mathrm{V}}$ of the $\mathrm{AC}$ voltages developed at the middle points $\mathrm{M}$ of the bacterial cell (see Figure 2) on each of the three layers constituting the cell wall (outer-membrane $\bullet$, periplasm $\downarrow$, inner-membrane $\mathbf{m}$ ), when applying transversally an external electric field of amplitude $1 \mathrm{~V} / \mathrm{cm}$.

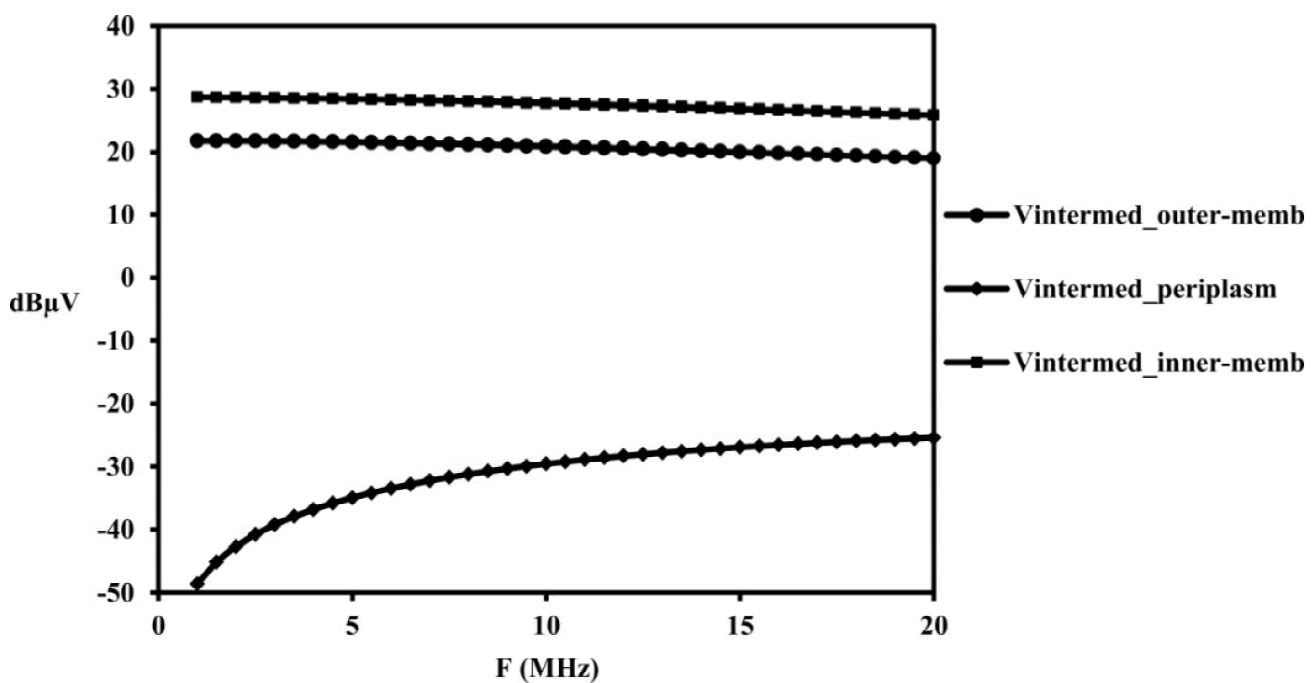

Figure 12 - Amplitude in $\mathrm{dB}_{\mu \mathrm{V}}$ of the $\mathrm{AC}$ voltages developed at the intermediate points $\mathrm{I}$ of the bacterial cell (see Figure 2) on each of the three layers constituting the cell wall (outer-membrane $\bullet$, periplasm $\bullet$, inner-membrane $\mathbf{~})$, when applying transversally an external electric field of amplitude $1 \mathrm{~V} / \mathrm{cm}$. 


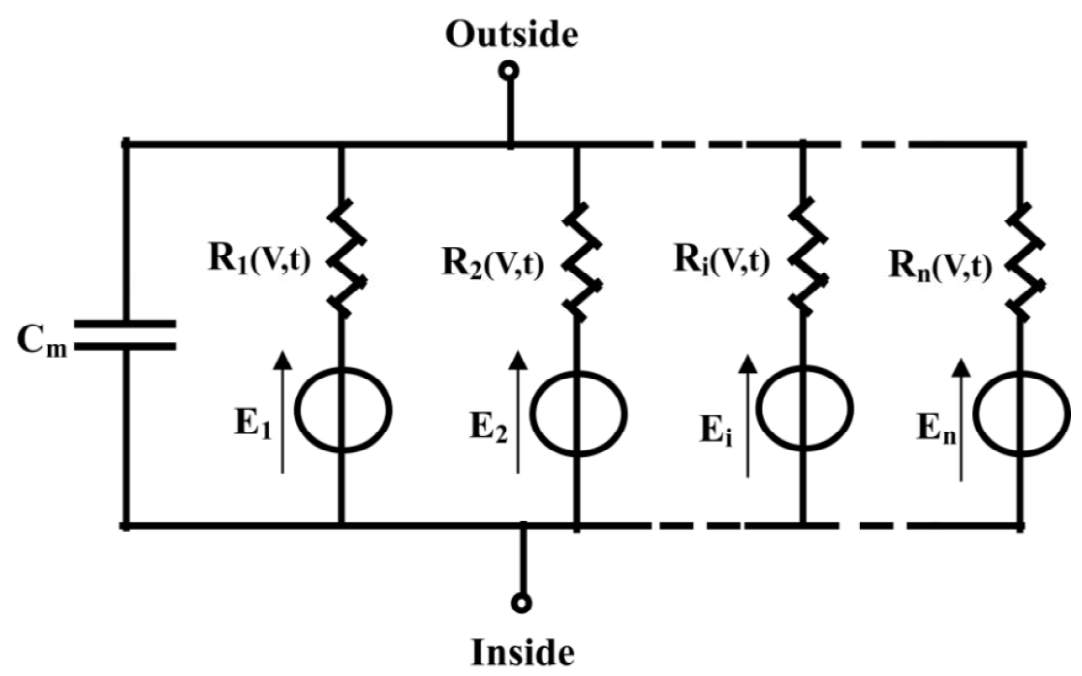

Figure 13 - Proposal of the general structure of a surface membrane element with ionic exchanges. This model, inspired by the HHK (Hodgkin, Huxley \& Katz) theory, is non-linear a priori, the resistors $\mathrm{R}_{\mathrm{i}}(\mathrm{V}, \mathrm{t})$ being dependent on the voltage at their terminals and time [Hodgkin et al, 1952]. 
Table 2 - Specific resistances and capacitances calculated for the three sublayers of E. coli cell wall, with $\mathrm{S}=10^{-8} \mathrm{~m}^{2}$

\begin{tabular}{|c|c|c|c|c|}
\hline$F^{\prime}$ & $F^{\prime}$ & $F_{\text {outer-memb }}$ & $F_{\text {periplasm }}$ & $F_{\text {inner-memb }}$ \\
\hline $102 \mathrm{kHz}$ & $881 \mathrm{MHz}$ & $149 \mathrm{kHz}$ & $961 \mathrm{MHz}$ & $327 \mathrm{~Hz}$ \\
\hline
\end{tabular}

Table 3 - Cut-off frequencies occurring in the transfer functions expressed as in equation (11). Subscript i refers to the layer on which the voltage is calculated and then divided by the total cell wall voltage, while subscripts $j$ and $k$ refer to the other layers. For example, if " $i$ " is "outer-layer", then " $j$ " is "periplasm" and " $\mathrm{k}$ " is "inner-layer".

\begin{tabular}{|c|c|c|c|}
\hline & Outer membrane & Periplasm & Inner membrane \\
\hline $\lim _{\mathrm{F} \rightarrow 0}\left(\mathrm{~T}_{\mathrm{i}, \mathrm{dB}}\right)$ & $-60 \mathrm{~dB}$ & $-147 \mathrm{~dB}$ & $8 \times 10^{-3} \mathrm{~dB} \approx 0 \mathrm{~dB}$ \\
\hline $\lim _{\mathrm{F} \rightarrow \infty}\left(\mathrm{T}_{\mathrm{i}, \mathrm{dB}}\right)$ & $-10,9 \mathrm{~dB}$ & $-21,7 \mathrm{~dB}$ & $-4 \mathrm{~dB}$ \\
\hline
\end{tabular}

Table 4 - Limit values of transfer functions for the three layers of the cell wall. 